\title{
Review \\ Precision and Advanced Nano-Phytopharmaceuticals for Therapeutic Applications
}

\author{
Chooi Ling Lim ${ }^{1, *}$, Chandramathi S. Raju ${ }^{2, *}$, Tooba Mahboob ${ }^{2}$, Sunil Kayesth ${ }^{3, *}$, Kamal K. Gupta ${ }^{3}$, \\ Gaurav Kumar Jain ${ }^{4}$, Mahaveer Dhobi ${ }^{4}$, Muhammad Nawaz ${ }^{5}$, Polrat Wilairatana ${ }^{6, *(D)}$, \\ Maria de Lourdes Pereira ${ }^{7}$ (D) Jayanta Kumar Patra ${ }^{8}\left(\mathbb{D}\right.$, Alok K. Paul ${ }^{9}$, Mohammed Rahmatullah ${ }^{10}(\mathbb{D})$ and \\ Veeranoot Nissapatorn ${ }^{11, *}$
}

check for updates

Citation: Lim, C.L.; Raju, C.S.; Mahboob, T.; Kayesth, S.; Gupta, K.K.; Jain, G.K.; Dhobi, M.; Nawaz, M.; Wilairatana, P.; de Lourdes Pereira, M.; et al. Precision and Advanced Nano-Phytopharmaceuticals for Therapeutic Applications. Nanomaterials 2022, 12, 238. https:// doi.org/10.3390/nano12020238

Academic Editors: Eun-Bum Cho, Jongnam Park and Shin Sik Choi

Received: 21 December 2021

Accepted: 8 January 2022

Published: 12 January 2022

Publisher's Note: MDPI stays neutral with regard to jurisdictional claims in published maps and institutional affiliations.

Copyright: () 2022 by the authors Licensee MDPI, Basel, Switzerland. This article is an open access article distributed under the terms and conditions of the Creative Commons Attribution (CC BY) license (https:// creativecommons.org/licenses/by/ $4.0 /)$.
1 Division of Applied Biomedical Science and Biotechnology, School of Health Sciences, International Medical University, Kuala Lumpur 57000, Malaysia

2 Department of Medical Microbiology, Faculty of Medicine, University of Malaya, Kuala Lumpur 50603, Malaysia; tooba666@hotmail.com

3 Department of Zoology, Deshbandhu College, University of Delhi, New Delhi 110019, India; kgupta@db.du.ac.in

4 Department of Pharmacognosy and Phytochemistry, Delhi Pharmaceutical Sciences and Research University (DPSRU), New Delhi 110017, India; gkjain@dpsru.edu.in (G.K.J.); mahaveer@dpsru.edu.in (M.D.)

5 Department of Nano-Medicine, Institute for Research and Medical Consultations ((IRMC), Imam Abdulrahman Bin Faisal University, Dammam 34212, Saudi Arabia; mnnmuhammad@uod.edu.sa

6 Department of Clinical Tropical Medicine, Faculty of Tropical Medicine, Mahidol University, Bangkok 10400, Thailand

7 CICECO-Aveiro Institute of Materials \& Department of Medical Sciences, University of Aveiro, 3810-193 Aveiro, Portugal; mlourdespereira@ua.pt

8 Research Institute of Biotechnology \& Medical Converged Science, Dongguk University-Seoul, Goyang-si 10326, Korea; jkpatra@dongguk.edu

9 School of Pharmacy and Pharmacology, University of Tasmania, Private Bag 26, Hobart, TAS 7001, Australia; alok.paul@utas.edu.au

10 Department of Biotechnology \& Genetic Engineering, University of Development Alternative, Lalmatia, Dhaka 1207, Bangladesh; rahamatm@hotmail.com

11 School of Allied Health Sciences and World Union for Herbal Drug Discovery (WUHeDD), Walailak University, Nakhon Si Thammarat 80160, Thailand

* Correspondence: chooi_linglim@imu.edu.my (C.L.L.); chandramathi@um.edu.my (C.S.R.); skayesth@db.du.ac.in (S.K.); polrat.wil@mahidol.ac.th (P.W.); veeranoot.ni@wu.ac.th (V.N.)

\begin{abstract}
Phytopharmaceuticals have been widely used globally since ancient times and acknowledged by healthcare professionals and patients for their superior therapeutic value and fewer sideeffects compared to modern medicines. However, phytopharmaceuticals need a scientific and methodical approach to deliver their components and thereby improve patient compliance and treatment adherence. Dose reduction, improved bioavailability, receptor selective binding, and targeted delivery of phytopharmaceuticals can be likely achieved by molding them into specific nano-formulations. In recent decades, nanotechnology-based phytopharmaceuticals have emerged as potential therapeutic candidates for the treatment of various communicable and non-communicable diseases. Nanotechnology combined with phytopharmaceuticals broadens the therapeutic perspective and overcomes problems associated with plant medicine. The current review highlights the therapeutic application of various nano-phytopharmaceuticals in neurological, cardiovascular, pulmonary, and gastro-intestinal disorders. We conclude that nano-phytopharmaceuticals emerge as promising therapeutics for many pathological conditions with good compliance and higher acceptance.
\end{abstract}

Keywords: nano-formulations; phytopharmaceuticals; herbal medications; therapeutics; precision 


\section{Introduction}

Nanotechnology is the application of nanoparticles for various purposes, including disease diagnostics, cosmetics, and therapeutics. From a small beginning in the 1950s by the physicist Richard Feynman and in 1974 by Norio Taniguchi, the applications of nanotechnology have changed to an enormous dimension today, and are encompassing many branches of chemistry, physics, biochemistry, biotechnology, information technology, environmental science, and pharmacy, to name only a few [1]. Nanotechnology is a vital tool for medical sciences. The introduction of nanomedicine, using nanotechnology combined with drugs or diagnostic molecules, has improved the ability to target specific cells or tissues that require treatment and repair. These nanomaterials have been proven to be produced at a nanoscale level and are safe to introduce into the body. It is possible to modify a variety of nanocarriers' characteristics that include their constituents, size, shape, bioavailability, surface properties, and target specificity to achieve or enhance desirable pharmacological targets [1,2] Several strategies have been implemented to increase the drug-target specificity. Recently, several studies have reported improved efficacy of therapy when combined with nanomaterials [3]. Pure herbal medicines are often considered less effective compared to pure constituents that are mainly demonstrated to have reduced intestinal absorption when administered orally [4]. This is the reason behind the pharmacological activity/loss associated with pure constituents and such problems can be overcome using new drug delivery systems, such as nanotechnology.

Nanoparticulate delivery of drugs can generally improve drugs' solubility, bioavailability, stability, pharmacological activity, increase target specificity, promote transport across membrane, prolong circulation times, and reduce systemic and organ toxicity $[5,6]$. Various treatments are being investigated with the use of nanoparticle drug delivery systems for diseases, such as infectious diseases, autoimmune diseases, cardiovascular diseases, neurodegenerative diseases, ocular diseases, fungal infections, iron deficiency, and pulmonary diseases $[7,8]$. However, the greatest advances were seen in the treatment of cancer with several nano strategies being used clinically after approval by the FDA in the United States of America [9]. Recently, more attention has shifted towards novel drug delivery systems using nanoparticles for herbal and plant-based drugs [10]. The use of plants for medicinal purposes can be documented from as far back as 6000 years ago with many important plant compounds being developed into conventional or allopathic medicine used today [11]. Although conventional medicine is widely used compared to herbal medicine in developed countries, there is a considerably large segment of society that continues to use medicines derived from plants for their healthcare [12].

According to the World Health Organization, nine million Malaysians out of an estimated population of 30 million would have used or are using traditional and complementary medicines (which includes plants, parts of plants, or plant materials) for the prevention and treatment of medical ailments. Additionally, $88 \%$ of WHO member states (170 of the 194 member states) have acknowledged their use of traditional and complementary medicine amongst their population [13].

Despite these numbers, plant-based medicine has some limitations which hinder its use and production in the mainstream disease treatment and therapy. There are several chemical constituents in a plant's extract that lead to its medicinal properties. The active constituents of plant extracts like tannins, flavonoids, alkaloids, phenylpropanoids, and terpenoids are water-soluble but show poor absorption from their inability to cross lipid membranes and have large molecular sizes, which then results in low bioavailability and efficacy $[5,12,14]$. There are also concerns of safety due to the incompatibility of some plant extracts with other components in a drug formulation which can lead to undesirable effects [12]. High systemic clearance of these compounds also leads to low therapeutic levels in the blood resulting in no therapeutic effect [15]. Furthermore, poor reproducibility of in vitro effects in vivo prevents many plant-based medicines from clearing clinical trial phases [16]. Nanomedicine aims to overcome these limitations and to improve the delivery of plant-based medicines to treat various diseases. Nanoparticle drug delivery systems 
can potentially improve the stability, solubility, and bioavailability of encapsulated plant extracts, promote its movement across lipid membranes, and prolong its circulation, all while delivering the active constituent to a specific target site $[5,6,12]$ (Figure 1). Liposomes, dendrimers, polymeric NCs, polymeric micelles, metallic NPs (magnetic, gold), SLNs, nanocapsules, nanospheres, and nanogels are some of the examples of nano-based drug delivery systems that are presently under investigation [10]. This review aims to show the potential of plant-based drugs to prevent and treat some of the communicable and noncommunicable diseases. Although not exhaustive, this review highlights several examples where the application of nanotechnology proves to be effective.

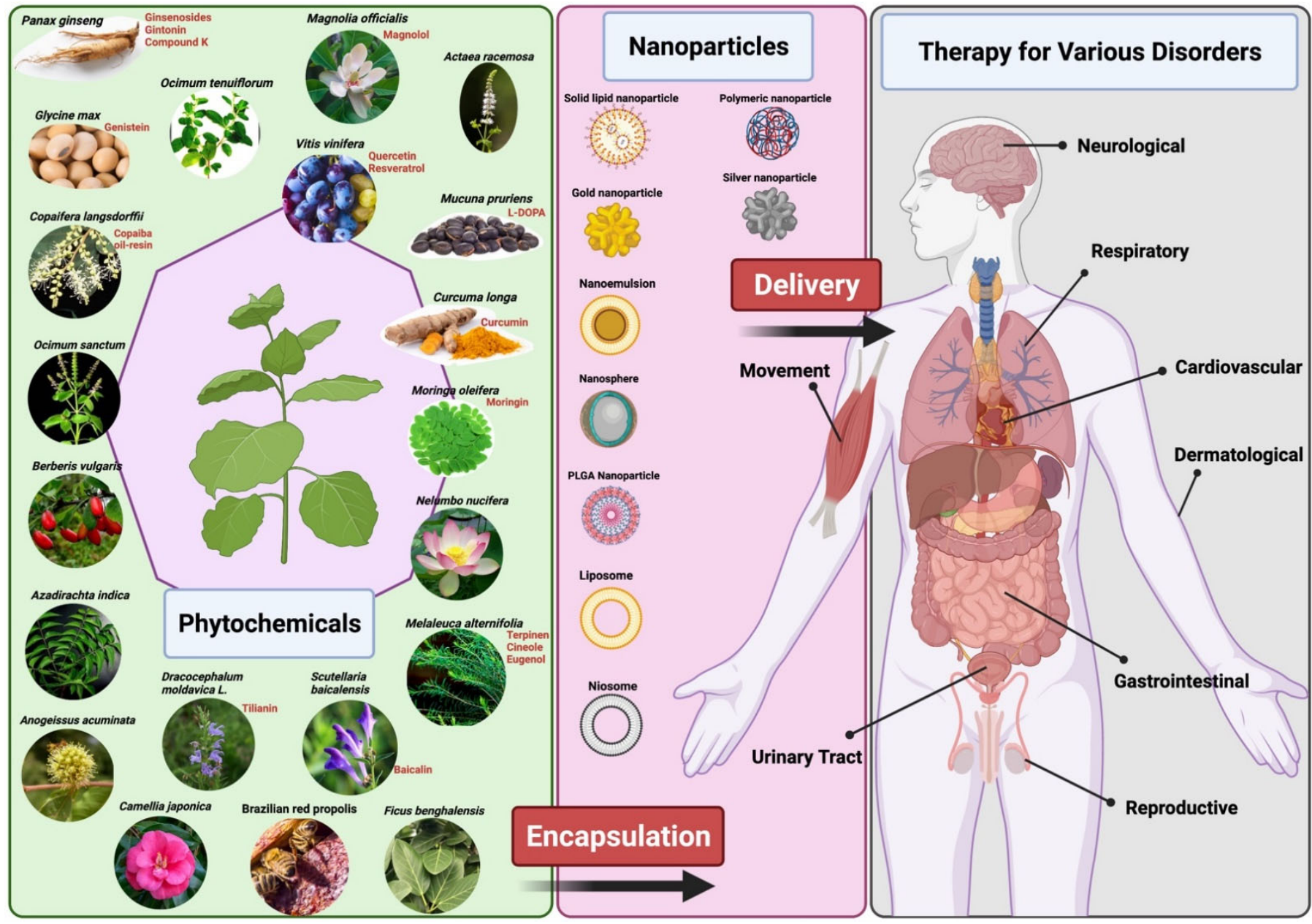

Figure 1. Representation of delivery of phytopharmaceuticals using nanotechnology. The figure was made with www.biorender.com (access date: 17 December 2021).

\section{Materials and Methods}

Databases including PubMed, Medline, Scielo, Thomson Reuters ISI Web of Knowledge, and Science Direct were searched, combining the following keywords: "Nanotechnology", "plant-based medicine", "herbal nanoformulations", "phytochemical-based nanoformulations", and "nano-phytopharmaceuticals". The available scientific literature within the last decade (2011-2021) was considered in this review.

\section{Therapeutic Applications of Nano-Phytopharmaceuticals}

\subsection{Nano-Phytopharmaceuticals in Neurological (CNS) Disorders}

The central nervous system is a complex environment-a vast network of neurons, astrocytes, microglia, and other supportive tissues buoyed in lubricating cerebrospinal fluid. The delicate balance between nerve connections, spinal cord, and the control center, the 
brain, is easily perturbed by exogenous insults and endogenous degenerative conditions. Debilitating disorders of the central nervous system (CNS) include Alzheimer's disease (AD) [17] and variants of dementia such as Lewy body dementia (LBD), tumors such as neuroblastoma and glioblastoma [18], as well as dyskinesia-related conditions such as Parkinson's disease (PD), Huntington's disease (HD), and amyotrophic lateral sclerosis (ALS) [19]. Alzheimer's disease is a type of neurodegenerative disease that is described by the formation of plaques with tangled neurofibers composed of amyloid and tau proteins. It is recognized as the most common type of dementia and the main risk factor is associated with age [20]. Parkinson's disease is described by the deficiency of dopamine neurons in the substantia nigra. It has been associated with the aggregation of ubiquitinated synuclein in the dopaminergic neurons [20]. It is estimated that $1 \%$ of individuals over 60 years of age are affected by Parkinson's disease, which is the main source of the movement disorder known as Parkinsonism [20]. Parkinsonism comprises tremors, bradykinesia, and akinesia in severe cases [21]. Huntington's disease is described by the accumulation of a mutant Huntingtin protein in the neurons, prompting inaccurate neuronal actions and eventually results in neuronal demise [22]. This prompts unusual movements in the patient, adduced as chorea [23]. The cause of Huntington's disease is the autosomal dominant mutation [20]. The pathophysiology underlying CNS diseases involve neuroinflammation, accumulation of distorted protein aggregates [24], and neuronal death [25].

The CNS and related diseases represent a serious health burden globally [26]. The therapy to treat CNS disorders is mainly hampered by the blood-brain barrier (BBB). BBB is a highly organized arrangement of the vasculature that has evolved naturally to restrict the entrance of molecules into the brain and to prevent the brain from potentially harmful microbes, to prevent microbials entering the bloodstream. Following these restrictions, most known therapies face the same hindrance from the BBB in entering the CNS and targeting the site of infection [27], whereas the BBB slowly allows the passage of nutrients and other related molecules with a smaller size which are a necessary function of the CNS [28].

Despite enduring efforts to deliver medicinal drugs to the brain tissue, these treatment regimens are compromised by low bioavailability due to the blood-brain barrier (BBB), a natural protective layer consisting of capillary endothelial cells, pericytes, and tight junctions [29]. This near-impermeable barrier impedes the entry of most macromolecules and allows only the minutest particles $(<400 \mathrm{Da})$ to cross into the nerve tissue. Indeed, less than $5 \%$ of conventional therapeutic molecules in various stages of pharmaceutical development may penetrate this physiological barrier [30]. Therefore, CNS-targeted natural product formulations in nanocarriers hold infinite promise. Evidence suggests that nutraceuticals and phytochemicals exert therapeutic effects in neurological diseases, owing to their antioxidant, anti-inflammatory, and neuroprotective mechanisms [31,32]. Coupled with nanoscale delivery systems which improve solubility, enhance retention rates [33], and with the ability to permeate through the BBB (Figure 1), there is hope yet for effective treatment of neurological disorders. The following topic discusses two herbal compounds, curcumin and ginseng, and their significant potential for use in neurotherapeutics through nano-encapsulation.

A derivative of the South Asian turmeric plant rhizome, Curcuma longa (turmeric), the polyphenol curcumin has amassed quite a reputation in nutraceutical development for various diseases, including cancer and inflammatory conditions [34]. The healing properties of this yellow spice date back to ancient civilizations, featuring strongly in Ayurvedic therapy. Nevertheless, the relatively poor bioavailability due to dismal water solubility and rapid intestinal clearance impedes the therapeutic effects of conventional drug delivery, paving the way for the advent of nano-formulations.

The role of nanoparticulate systems to treat glioblastoma was recently highlighted using different strategies, such as improving their diffusion through the BBB [35]. In a glioblastoma study, Schmitt et al. demonstrated that curcumin encased in liposomal carriers (LipoCur) proved to be superior in reducing the proliferation and reactivity of 
human microglia and astrocytes (human fetal astrocyte cell line, SVGA) compared to the free compound. Immunostaining of murine organotypic brain segments challenged with lipopolysaccharide (LPS) for eight days, revealed that LipoCur was equally effective in reducing glial scarring [34].

Research on neuroblastoma models also corroborated that the anticancer properties of curcumin were significantly enhanced through nanocarrier delivery [36]. Curcumin nanosuspensions, consisting of stable nanoscale droplets of the compound with surfactants and biopolymers, improved solubilization and increased intravenous plasma distribution to vital organs compared with standard curcumin. Higher levels of curcumin in male Wistar rat brains were discovered when delivered via Tween 80-coated nanoparticles (NPs) in comparison to curcumin solution [37]. The mechanism of action exerted by curcumin in neuroblastoma cells involved the regulation of PTEN-Akt (phosphatase and tensin homolog-protein kinase B), NF- $\mathrm{kB}$ (nuclear factor kappa-light-chain-enhancer of activated $B$ cells), and p53 (tumor protein P53), signaling, activation of the apoptosis cascade, and mitochondrial dysfunction [36].

In another study, dextran-coated cerium oxide nanoparticles (CNP-Cur), containing curcumin, induced significant cell death in an in vitro model of neuroblastoma. The formulation enhanced oxidative stress and triggered caspase-dependent apoptosis targeted to MYCN-amplified tumor cells and sparing non-MYCN augmented populations [38]. The synthesis of nanoparticle shells themselves could use natural compounds, such as silk fibroin of the Bombyx mori silkworm. The biocompatible and biodegradable properties add to the allure of the curcumin-loaded silk fibroin NP formulation, which conferred enhanced and tumor-specific cytotoxicity in neuroblastoma cells [39].

Aside from pure curcumin, combinations of herbal compounds that exhibit synergistic effects were also a subject of interest. A $10-25 \mu \mathrm{g} / \mathrm{mL}$ curcumin-piperine combination loaded into zein-chitosan nanoparticles (CPZChN) successfully reduced SH-SY5Y neuroblastoma cell viability by half, with encapsulation efficiencies of $89 \%$ (curcumin) and $87 \%$ (piperine) respectively [40]. Multi-compound bioactive complexes like curcumin-piperine are challenging to create, due to their distinct polarities. To overcome this, the two components were encased in core-shell NPs through antisolvent precipitation and progressive layering of zein-hyaluronic acid, followed by chitosan coating [41].

Aside from the CNS cancers, chronic degenerative conditions such as Alzheimer's disease (AD) fall under intense scrutiny from researchers. Characterized by neurofibrillary tangles of tau proteins and "senile" amyloid- $\beta(\mathrm{A} \beta)$ plaques in the brain, the condition is notoriously challenging to diagnose and treat due to the late onset of symptoms, usually decades after the onset of pathological changes [42]. Neuro-inflammation is recognized as one of the primary mechanisms underlying neuronal degeneration, and thus is a target for natural product (NP) research. Malvajerd and colleagues encapsulated curcumin in solid lipid nanoparticles (SLNs) (entrapment efficiency $82 \pm 0.49 \%$ ) and nanostructured lipid carriers (NLCs) $(94 \pm 0.74 \%)$, and found that NLCs resulted in the highest bioaccumulation of curcumin in rat brains compared to free compound and SLNs [43].

A variant of lipid NPs, lipid-core nanocapsules (LNC), were used as curcumin carriers in an AD model of aged mice injected with $\beta$-amyloid 1-42 peptide. Significant behavioral changes indicating reversal of degeneration and reduced inflammatory cytokine levels were observed in the mice which received the loaded LNCs [44]. Recently, Nakama and colleagues proposed an analytical method to quantify curcumin and meloxicam in an LNC co-nanoencapsulation trial. They validated the encapsulation using a HPLC-DAD technique, which has been proven non-toxic to male Swiss mice [45].

Similar models, using curcumin-loaded SLNs (SCLNs) of about $86 \mathrm{~nm}$ in diameter, reduced LPS-induced neuroinflammation in BV-2 microglial cells by hindering nitric oxide (NO) production. Proinflammatory cytokines, including TNF (tumor necrosis factor)- $\alpha$, IL (interleukin)-1 $\beta$, and IL-6, were also more strongly inhibited compared to free curcumin [46]. Both in vitro and in vivo year-old 5xFAD mice models for SCLN delivery were evaluated by Maiti and colleagues, who reported enhanced curcumin penetration and neuroprotection. 
The assessment of $\mathrm{A} \beta$ plaque load and pre-frontal cortex (PFC) and hippocampus neuronal morphology revealed a down-regulation of pyknotic neurons and anti-inflammatory effect conferred by the curcumin NPs [47].

Poly (D,L-lactic acid-co-glycolic acid, PLGA) and polymer NPs are known to be biocompatible and thus show great potential in disarming neuroinflammation in another 5xFAD mice Alzheimer's disease model [48]. Huang and team also achieved positive outcomes using novel PLGA NPs added with a BBB-penetrating (cyclic CRTIGPSVC) peptide, and co-administering curcumin with $\mathrm{A} \beta$ generation inhibitor. Transgenic AD mice responded well to treatment, with improved spatial memory scores and enhanced 'new-object recognition' ability [49]. Co-administration with phytol and selenium in PLGA NPs have also been proven to inhibit $\beta$ amyloid aggregation in various AD models [50,51].

Venturing into intranasal delivery, Zhang et al. compared two different formulations, namely CUR-encapsulated chitosan-coated poly (lactic-co-glycolic acid) nanoparticles (CUR-CS-PLGA-NPs) and hydroxypropyl- $\beta$-cyclodextrin-encapsulated CUR (CUR/HP $\beta$ CD inclusion) complexes. Both showed anti-inflammatory potential in BV-2 cells and higher bioavailability in vivo, although the latter was evidently more effective by 1.12 fold (plasma)and 2.57 fold (brain) [52]. Other NP formulations include curcumin-conjugated superparamagnetic iron oxide (SPIO) particles $<100 \mathrm{~nm}$ in diameter, resulting in biocompatible curcumin magnetic nanoparticles (Cur-MNPs). Administration of Cur-MNPs to Tg2576 mouse brains revealed co-localization of the particles with amyloid plaques, enabling less invasive diagnosis of AD using MRI (magnetic resonance imaging) [53]. Clearly, curcumin-encapsulated NPs have captivated the pharmaceutical drug development sector for neurotheranostics and advancing to the next stage of clinical trials would be warranted.

Another 'superherb', with its medicinal use dating back to ancient Chinese and Korean civilizations, the ginseng plant (Panax ginseng C. A. Meyer) is traditionally consumed to enhance alertness, cognition, memory, and overall well-being. Its purported effects on the CNS form the basis of neurotherapeutic drug development from numerous ginseng-derived bioactive compounds such as ginsenoside, gintonin and Compound K. These phytochemicals have been evaluated for curative and preventive properties in neurodegenerative diseases, including AD, PD, HD, and even depression [54,55]. Mechanistic studies suggest anti-apoptotic, antioxidant, neurogenesis, and inhibition of amyloid beta aggregation [56] in AD studies. A detailed review of bioactive components of $P$. ginseng and their effects on AD pathogenesis was recently reported by Razgonova and colleagues [57].

Aalinkeel and team investigated the neuroprotective effect of Ginsenoside Rg3 combined with Thioflavin $T$, an $A \beta$ diagnostic, encased in biodegradable PLGA NPs. An in vitro model was used to evaluate the efficiency of BBB penetration and underlying mechanistic pathways of bioactivity. They concluded that PLGA-Rg3 NPs may prove to be a potent nanodelivery tool for the treatment of neurological disease [58]. Ginsenoside was also evaluated for anti-PD therapy through its antioxidant effect, modulation of glutathione level, ROS-mediated NF- $\mathrm{kB}$ signaling, iron transport, and subsequently reduced iron accumulation in the substantia nigra [31].

Other groups evaluated the bioactivity of Compound $\mathrm{K}(\mathrm{CK})$, a metabolite from the biotransformation of ginsenosides $\mathrm{Rb} 1, \mathrm{Rb} 2$, and Rc. Other well-studied ginsenosides include $\mathrm{Rd}, \mathrm{Re}$, and Rg131. As the most bioavailable component of ginsenoside metabolism, its neuroprotective and cognition-enhancing effects have been characterized in animal models of AD [59]. Although CK is regarded as safe and well-tolerated, findings from clinical trials are marginal and based on CK-rich fermented red ginseng. Delivery of CK through nanocarriers was reported to override its limitations of efflux, poor water solubility, and membrane permeability, which impeded the research progress into clinical trials $[60,61]$.

Kim et al. established a formulation of red ginseng water extract with gold nanoparticles (WERGGN) and established its antioxidant activity through DPPH, ORAC and ABTS assays. WERGGN treatment on neuron-like PC-12 cells revealed cytoprotective effects, mainly due to the decreased intracellular oxidative stress. In addition, levels of neurotrans- 
mitter degradation enzymes such as acetylcholinesterase and butyrylcholinesterase were also inhibited, suggesting that WERGGN promoted synaptic impulse transmission [62]. Nonetheless, the dosage of ginseng extract, when co-administered with a synthetic drug (e.g. selegiline), determines the pharmacokinetics in the body: lower doses result in poorer bioavailability due to CYP1A2 induction, while higher concentrations cause inhibition of CYP3A4 and thus enhanced systemic exposure [63].

Although the root of Panax ginseng is generally the primary source of extracted bioactive compounds, its leaves may be equally valuable. Singh et al. characterized and validated gold- and silver-NPs with fresh ginseng leaf extract, demonstrating significant antioxidant and anti-inflammatory activity, and anti-carcinogenic effects or biocompatibility in several tumorigenic or normal human cell lines, respectively [64]. Studies on the anti-carcinogenic effects of polymer-ginsenoside nanoconjugates revealed improved bioavailability into the tumor sites, efficient drug release, and oncogene-targeting mechanisms [65]. In a glioma spheroid model, Zhu et al. developed a multifunctional ginsenoside Rg3-based liposomal system (Rg3-LPs) which demonstrated a superior anti-proliferation effect on C6 glioma cells compared to cholesterol liposomes (C-LPs) when embedded with paclitaxel (PTX). In C6-bearing mice/ / rats, Rg3-PTX-LPs triggered expansion of CD8+T-cell populations, thus enhancing cancer-ridding immune surveillance. The researchers surmised that ginsenoside $\operatorname{Rg} 3$ shows a synergistic effect with synthetic chemotherapy drugs and provides an effective delivery tool for neurological tumors [66]. In another study, a nano-ginseng formulation, 'ginsenoside Rb1/protopanaxadiol nanoparticles' (Rb//PPD NPs) of 110 nm in size, showed increased drug-loading efficiency $(\sim 96.8 \%)$ and capacity $((\sim 27.9 \mathrm{wt} \%)$, although this was targeted on the Lewis lung cancer (LLC) cell line and xenograft [67].

In a nutshell, derivatives of Panax ginseng display great potential in the treatment of neurodegenerative conditions as well as various cancers, including gliomas, and should be explored further (Figure 2). Nano-formulations of active compounds or extracts from curcumin and ginseng for neurological disorders described in this topic are briefly listed in Table 1.

It is essential to note that nanomaterials have potential limitations and the adverse effects on CNS were described previously [69,70]. For example, one study showed that female mice that were intranasally treated with titanium dioxide nanoparticles $\left(\mathrm{TiO}_{2} \mathrm{NPs}\right)$ (0.5 mg daily for 1 month) produced apoptosis, affected brain development, and oxidative stress (caused increased lipid peroxidation, protein oxidation, catalase expressions, and release of glutamic acid and nitric oxide) [70]. These authors also concluded that an intranasal spray of $\mathrm{TiO}_{2}$ NPs could be translocated into the CNS and cause potential lesions of the brain [70]. Similarly, $\mathrm{Fe}_{2} \mathrm{O}_{3}$ magnetic NPs $(0.15-15 \mathrm{mM})$ also showed toxicity and c viability in a neuronal cell line in vitro [71]. Whereas another study showed that toxicity of zinc and silicon NPs is relatively low, but the neuronal toxicity of NPs depends on the materials used $[69,72,73]$. Therefore, the toxicity of NPs is present, and depends on the formulation, particle size and concentration or treatment protocols of specific NPs. 
Table 1. Nano-formulations of active compounds or extracts from curcumin and ginseng for neurological disorders.

\begin{tabular}{|c|c|c|c|}
\hline Nanoformulation & Phyto-Pharmaceutical & Effect & References \\
\hline \multirow[b]{2}{*}{ Liposomal carriers } & Curcumin (LipoCur) & $\begin{array}{l}\text { Reduced proliferation and reactivity of human } \\
\text { microglia and astrocytes; reduced glial scarring }\end{array}$ & [34] \\
\hline & $\begin{array}{l}\text { Ginsenoside Rg3 in } \\
\text { combination with paclitaxel } \\
\text { (Rg3-PTX-LPs) }\end{array}$ & $\begin{array}{l}\text { Anti-proliferative effect on C6 glioma cells; } \\
\text { triggered expansion of CD8 + T-cell populations } \\
\text { in C6-bearing mice/rats }\end{array}$ & {$[66]$} \\
\hline $\begin{array}{l}\text { Tween } 80 \text {-coated } \\
\text { nanoparticles }\end{array}$ & Curcumin & $\begin{array}{l}\text { Higher accumulation of curcumin in Wistar rats; } \\
\text { improved solubilisation and plasma distribution } \\
\text { to vital organs }\end{array}$ & [37] \\
\hline $\begin{array}{l}\text { Dextran-coated cerium oxide } \\
\text { nanoparticles }\end{array}$ & Curcumin (CNP-Cur) & $\begin{array}{l}\text { Enhanced cell death in neuroblastoma cells } \\
\text { through caspase-dependent apoptosis }\end{array}$ & {$[38]$} \\
\hline Silk fibroin nanoparticles & Curcumin & $\begin{array}{l}\text { Enhanced tumour-specific toxicity in } \\
\text { neuroblastoma cells }\end{array}$ & {$[39]$} \\
\hline Zein-chitosan nanoparticles & $\begin{array}{l}\text { Curcumin-piperine } \\
\text { combination }(\mathrm{CPZChN})\end{array}$ & $\begin{array}{l}\text { Reduced SH-SY5Y neuroblastoma cell viability } \\
\text { by half }\end{array}$ & {$[40]$} \\
\hline \multirow{3}{*}{$\begin{array}{l}\text { Solid lipid nanoparticles } \\
\text { (SLNs); Nanostructured lipid } \\
\text { carriers (NLCs) }\end{array}$} & \multirow{3}{*}{ Curcumin } & $\begin{array}{l}\text { Highest bioaccumulation of curcumin in rat } \\
\text { brains compared to free compound and SLNs }\end{array}$ & {$[43]$} \\
\hline & & $\begin{array}{l}\text { Reduced LPS-induced neuroinflammation in } \\
\text { BV-2 microglial cells }\end{array}$ & {$[68]$} \\
\hline & & $\begin{array}{l}\text { Downregulation of pyknotic neurons and } \\
\text { anti-inflammatory effect }\end{array}$ & [47] \\
\hline $\begin{array}{l}\text { Lipid-core nanocapsules } \\
\text { (LNC) }\end{array}$ & Curcumin & $\begin{array}{c}\text { Reversal of degeneration and reduced } \\
\text { inflammatory cytokine levels in AD mice model }\end{array}$ & [44] \\
\hline \multirow{3}{*}{$\begin{array}{c}\text { Poly (D,L-lactic } \\
\text { acid-co-glycolic acid, PLGA) } \\
\text { polymer nanoparticles }\end{array}$} & Curcumin & Reduced neuroinflammation in 5xFAD mice & {$[48]$} \\
\hline & $\begin{array}{l}\text { Curcumin co-administered } \\
\text { with phytol and selenium }\end{array}$ & Inhibited $\beta$ amyloid aggregation in AD models & {$[50,51]$} \\
\hline & $\begin{array}{l}\text { Ginsenoside Rg3 combined } \\
\text { with Thioflavin T }\end{array}$ & $\begin{array}{l}\text { Effective penetration of an in vitro blood-brain } \\
\text { barrier }\end{array}$ & {$[58]$} \\
\hline $\begin{array}{l}\text { Novel PLGA nanoparticles } \\
\text { added with a BBB-penetrating } \\
\text { (cyclic CRTIGPSVC) peptide }\end{array}$ & $\begin{array}{l}\text { Curcumin with } A \beta \text { generation } \\
\text { inhibitor }\end{array}$ & $\begin{array}{l}\text { Transgenic Alzheimer's disease mice had } \\
\text { improved spatial memory scores and enhanced } \\
\text { 'new-object' recognition }\end{array}$ & [9] \\
\hline
\end{tabular}

Chitosan-coated poly

(lactic-co-glycolic acid) nanoparticles

(CUR-CS-PLGA-NPs);

Hydroxypropyl- $\beta$ -

Curcumin Anti-inflammatory effect in BV-2 cells and higher bioavailability in vivo

cyclodextrin-encapsulated

CUR (CUR/HP- $\beta-C D$

inclusion) complex

Curcumin-conjugated superparamagnetic iron oxide

(SPIO) particles; magnetic

Curcumin (Cur-MNPs)

Co-localisation of particles with amyloid plaques, nanoparticles enabling less invasive (MRI-based) AD diagnosis

Cytoprotective effect on neuron-like PC-12 cells

Red ginseng water extract due to decreased intracellular oxidative stress; promotion of synaptic impulse transmission

Gold and silver nanoparticles

Fresh ginseng leaf extract
Antioxidant, anticancer and anti-inflammatory activities in HaCaT cells, 3T3-L1 pre-adipocyte cells, A549 lung cancer and B16BL6 skin melanoma cancer cell lines and RAW 264.7 cell 


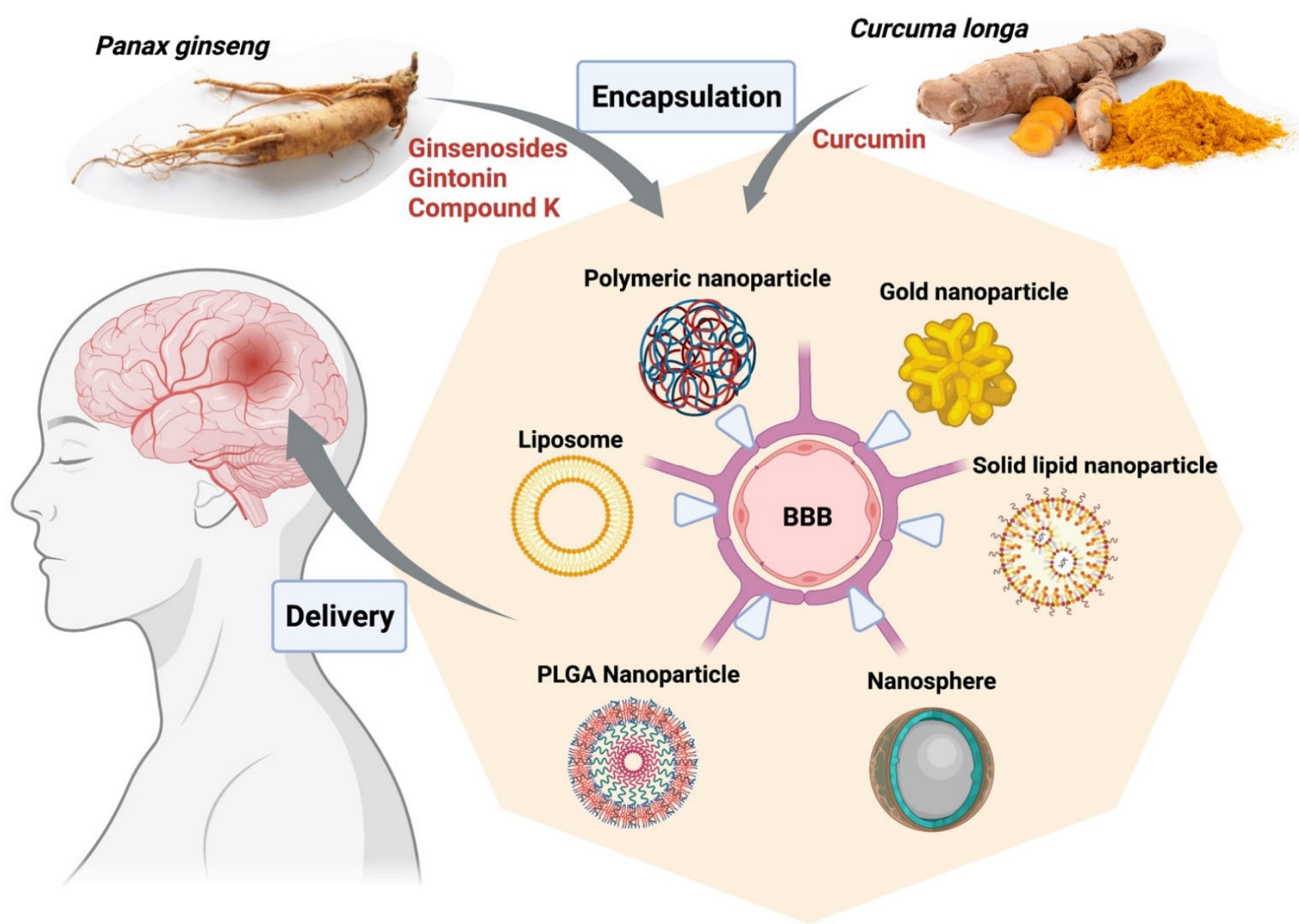

Figure 2. Encapsulation of bioactive compounds from herbal extracts of Curcuma longa and Panax ginseng into various nanoparticle platforms facilitates delivery to targeted areas in the brain from the blood, improves solubility, and enhances retention rates. The figure was made with www.biorender. com (access date: 12 January 2022). Abbreviations: BBB, blood-brain barrier; PLGA, poly (D,L-lactic acid-co-glycolic acid).

\subsection{Nano-Phytopharmaceuticals in Cardiovascular Disorders}

Cardiovascular disorders are linked to the heart and blood vessels, implicating coronary heart diseases (e.g., heart attack), cerebrovascular disease (e.g., stroke), elevated blood pressure (e.g., hypertension), peripheral artery disorders, rheumatic heart disease, congenital heart disease, and heart failure [74]. A large number of individuals die of cardiovascular diseases yearly compared to other diseases around the globe [74]. The risk factors associated with cardiovascular disorders mainly include tobacco use, unhealthy diet and obesity, lack of physical activity, inappropriate use of alcohol, hypertension, diabetes, and hyperlipidaemia [75]. Cardiovascular disorder refers to a condition that affects the heart or blood vessels mostly associated with deposits of fats in the arteries, a condition specifically known as atherosclerosis that can lead to blood clots. Most often, CVD is associated with damage to the arteries, not only of the heart, but also of other major organs, such as kidneys, brain, and eyes [76]. It is one of the leading causes of death worldwide. Noticeably, some pressing concerns are related to rising heart disease mortality rates among younger adults [77] A wide range of complications may emerge within cardiovascular systems, such as rheumatic heart disease, endocarditis, and abnormal conduction system [78]. There are many different types of CVD, but the main four are (i) Coronary heart disease (CHD) which occurs when the flow of oxygenated blood to the heart muscle is reduced or totally blocked. This condition leads to angina, heart attack, and heart failure; (ii) Stroke 
and transient ischemic attack (TIA), both conditions block the blood supply to the brain, but the former can cause brain damage and possibly death, while the latter brings about temporary interruption of blood flow to the brain, hence it is called a 'mini-stroke'; (iii) Peripheral arterial disease happens when the blockage of arteries involves the limbs, often the legs; (iv) Aortic disease involves the biggest artery, the aorta. This artery weakens and bulges outwards, and may be life-threatening due to its possible bursting that could lead to profuse bleeding $[77,79]$.

Cardiovascular disorders, associated with many factors, involve various congenital and acquired ailments. Cardiovascular disorders include atherosclerosis with its subtypes, such as coronary, cerebral, and peripheral artery disease, along with two main complexities, myocardial infarction and ischemic stroke, heart failure, cardiac valvulopathies and arrhythmias, rheumatic heart disease, congenital heart disease, deep vein thrombosis with its specific complexities, and pulmonary embolism [80]. It comprises the main noncommunicable reason for death in Europe specifically, and also globally [80].

CVD requires immediate attention and treatment to prevent further damage to avoid harmful clots from forming in blood vessels and plaque build-up [81]. Medications are any one or combinations of the following: anti-coagulants, anti-platelet agents, dual antiplatelet therapy, angiotensin-converting enzyme (ACE) Inhibitors, angiotensin II receptor blockers, angiotensin receptor-neprilysin inhibitors, beta blockers, calcium channel blockers, cholesterol-lowering medications, digitalis preparations, diuretics, and vasodilators [81,82]. Each type of medication has a specific action to prevent the formation of a blood clot that could cause a blockage in the blood vessel. In worst conditions, patients may undergo medical procedures such as coronary angioplasty and stent implantation, thrombolytic therapy, coronary artery bypass graft surgery (CABG), artificial pacemaker surgery, defibrillation, and heart valve surgery [82]

Since CVD require most often long-term medication, treatment regimens become complex and create a burden for the patient especially when multiple medicines are prescribed and must be taken for life [83,84] Although these therapeutic drugs have been successful in halting the progression of the disease, thereby improving the quality of life of patients, most of these cure only the symptoms and may not repair or regenerate the damaged tissues. In addition, CVD medication has different side effects, such as antiplatelet drugs may cause diarrhea, rash, or itching [83]. Others can cause abdominal pain, headache, chest pain, muscle aches, and dizziness. In the case of anticoagulants, their side effects can lead to bleeding and necrotic or gangrenous skin. Given the excessive side effects of current therapies, alternative therapeutic approaches like medicinal plants and natural products are preferred. Against this premise, a better treatment for CVD that would not burden the patients is necessary. Hence, it is important to explore new technologies and drugs to lessen the use of conventional treatments. The lower toxicity, chemical diversity, cost-effectiveness, and therapeutic potentials of natural products make them the popular choice of medicine compared to other products [85]. With the combination of nanoformulation methods to deliver phytomedicines, it becomes more effective with improved solubility, bioavailability, circulation time, surface area-to-volume ratio, nil systemic adverse side effects, and drug delivery efficiency of these medications. The introduction of nanomedicine using a combined nanotechnology with drugs or diagnostic molecules has improved the ability to target specific cells or tissues that require treatment and repair. These nanomaterials are produced on a nanoscale level and are safe to introduce into the body. Hence, applications for nanotechnology in medicine include imaging, diagnosis, or the delivery of drugs that will help medical professionals treat various diseases including cardiovascular diseases [86,87]. The functionality of the most recent nano-formulated medicinal plants and/or natural products against various cardiovascular conditions such as hypertension, atherosclerosis, thrombosis, and myocardial infarction is expected to be maximized.

Some plant extracts/compounds used for treatment of CVD that are nano-formulated for efficient delivery to their target are listed in Table 2. Among the extracts used for 
CVD, curcumin, quercetin, and resveratrol were the most applied natural products, respectively. However, curcumin, despite its curative potential, has poor aqueous solubility and consequently, minimal systemic bioavailability along with rapid degradation [88]. These characteristics restrict the utilization of curcumin at medical perspective. Liposomes have found uses in drug delivery of poorly water-soluble drugs. Such drug-loaded liposomes can be fabricated by a wide variety of nanotechnology methods such as ethanol injection, thin-film hydration, sonication, high-pressure extrusion, reverse-phase evaporation, calcium-induced fusion, and supercritical fluid methods, among others [88].

Quercetin acts as an antioxidant on cells but is hindered by its high metabolism rate. In order to control this, quercetin is encapsulated in poly [lactic-co-glycolic] acid (PLGA) nanoparticles [89]. This guarantees secure and controlled release of the quercetin, and permits cell enlistment, attachment, expansion, and articulation of heart proteins in local myocardium.

Resveratrol's capacity for protective action makes it one of the commonly used compounds against CVD. However, its poor pharmacokinetic properties, such as low aqueous solubility, low photostability and extensive first-pass metabolism, result in poor bioavailability and hinder its clinical potential $[90,91]$. To resolve this issue, the use of lipid nanoparticles offer the possibility to develop new therapeutics. Further, solid lipid nanoparticles hold great promise for reaching the goal of controlled and site-specific drug delivery [85].

Other compounds used for CVDs are Magnolols, Berberine, Tilianin and Baicalin. These compounds require nanoformulation to maximize their use. Magnolols as a phenolic polyhydroxy compound have poor aqueous solubility and low oral bioavailability which limit their clinical use. Therefore, various formulations such as liposomes [92], solid dispersions [93], emulsions [94], and nanoparticles [95] have been developed to ameliorate the water solubility and bioavailability of it (Figure 3). On the other hand, Berberine (BBR) has low bioavailability and also shows poor absorption through the gut wall $(<5 \%)$ and bowel glycoprotein appears to contribute to its poor absorption, actively expelling the alkaloid from the lumen mucosal cells, hence the use of liposomes as nanoformulation works best for BBR $[85,96]$. Studies have shown that Tilianin eases ischemia-reperfusioninduced cardiomyocyte injury. However, its full effectiveness is prevented because of its insolubility in water. The use of nanoformulation based on Tilianin nano-micelles overcomes this obstacle, as does the polyethylene glycol compound, covalently attached to propylene sulfide-formed amphiphilic diblock polymers [97]. In the aqueous solution, Tilianin is encapsulated in a hydrophobic shell to form nano-micelles $[85,97]$. The Ph-PPSPEG self-assembles into nanoscale micelles with a size of approximately $70 \mathrm{~nm}$, termed "Tilianin-loaded micelles" (TLMs).

NPs have shown some adverse effects on cardiovascular systems previously. Mice exposed to zinc NPs in the stomach ( $5 \mathrm{mg} / \mathrm{kg}$ body weight) experienced cardiac impairment, increased lactate dehydrogenase, creatinine kinase and aspartate aminotransferase, which was lower in zinc microparticles at the same dose [98,99]. Therefore, cardiac toxicity of zinc nanomaterials may be associated with particle sizes as per Wang and colleagues [99].

The rapid elimination half-life in plasma and poor water solubility of Baicalin (BN) limits its clinical efficacy. Aside from its short half-life and low water solubility, its bioavailability is low [100]. In order to enhance its clinical efficacy, the Novel Baicalin-loaded PEGylated nanostructured lipid carriers (BN-PEG-NLC) have been used to improve the bioavailability of $\mathrm{BN}$, to prolong retention time in vivo and to enhance its protective effect $[85,101,102]$. These nanotech applications aim to elude problems related to conventional drug delivery and possible negative systemic side effects. Once the nano-drug carriers have migrated locally, they provide the therapeutic payload delivery. This process eventually achieves therapeutic efficacy for a variety of cardiac disease indications [89]. 
Table 2. Nano-phytopharmaceuticals for therapeutic applications in CVDs.

\begin{tabular}{|c|c|c|c|}
\hline Nanoformulation & Phyto-Pharmaceutical & Effects & References \\
\hline Liposomes & Curcumin & $\begin{array}{l}\text { Anti-hypercholesterolemic, anti-atherosclerotic and protective } \\
\text { against cardiac ischemia and reperfusion. }\end{array}$ & [102] \\
\hline PLGA nanoparticle & Quercetin & $\begin{array}{l}\text { Anti-hypercholesterolemia, better cell rescue by lowering } \\
\text { oxidized thiols and sustaining superior ATP production, } \\
\text { improved therapeutics for ROS-based cardiac diseases. }\end{array}$ & [89] \\
\hline Solid lipid Nanoparticle & Resveratrol & $\begin{array}{l}\text { Protective action of vascular walls towards oxidation, } \\
\text { inflammation, platelet oxidation and thrombus formation }\end{array}$ & {$[103,104]$} \\
\hline $\begin{array}{l}\text { 1,2-diacyl-Sn-glycero-3- } \\
\text { phosphocholine [EPC] } \\
\text { and 1,2-dipalmitoyl-Sn- } \\
\text { glycero-3- } \\
\text { phosphocholine (DPPC) } \\
\text { liposomes }\end{array}$ & Magnolol & $\begin{array}{l}\text { Enhanced inhibitory effect on migration and hyperplasia of } \\
\text { vascular smooth-muscle cells; Anti-platelet, anti-thrombotic, } \\
\text { and anti-hypertensive via inhibiting MAPK family activation, } \\
\text { Akt/ERK1/2/GSK3 } \beta \text {-catenin pathway, and } \\
\text { angiotensin-converting enzyme (ACE)/angiotensin II (Ang } \\
\text { II)/Ang II type } 1 \text { receptor (AT-1R) cascade and upregulating } \\
\text { PPAR- } \beta / \gamma \text { and NO/guanosine } 3^{\prime}, 5^{\prime} \text {-cyclic phosphate/PKG. }\end{array}$ & {$[85,105,106]$} \\
\hline Nano-micelles & Tilianin & $\begin{array}{l}\text { Protective effects of cardiomyocytes by inhibiting } \\
\text { inflammation and oxidative stress during myocardial } \\
\text { ischemia-reperfusion injury }\end{array}$ & [99] \\
\hline $\begin{array}{l}\text { PEGylated } \\
\text { nanostructured lipid } \\
\text { carriers }\end{array}$ & Baicalin & $\begin{array}{l}\text { Improved myocardial ischemia; beneficial roles against the } \\
\text { initiation and progression of CVDs such as atherosclerosis, } \\
\text { hypertension, myocardial infarction, reperfusion and heart } \\
\text { failure }\end{array}$ & {$[100,101]$} \\
\hline Liposomes & Berberine & $\begin{array}{l}\text { Effect of protecting heart failure, hypertension, } \\
\text { hyperlipidemia, insulin resistance, arrhythmias, and platelet } \\
\text { aggregation. }\end{array}$ & {$[96,107]$} \\
\hline
\end{tabular}

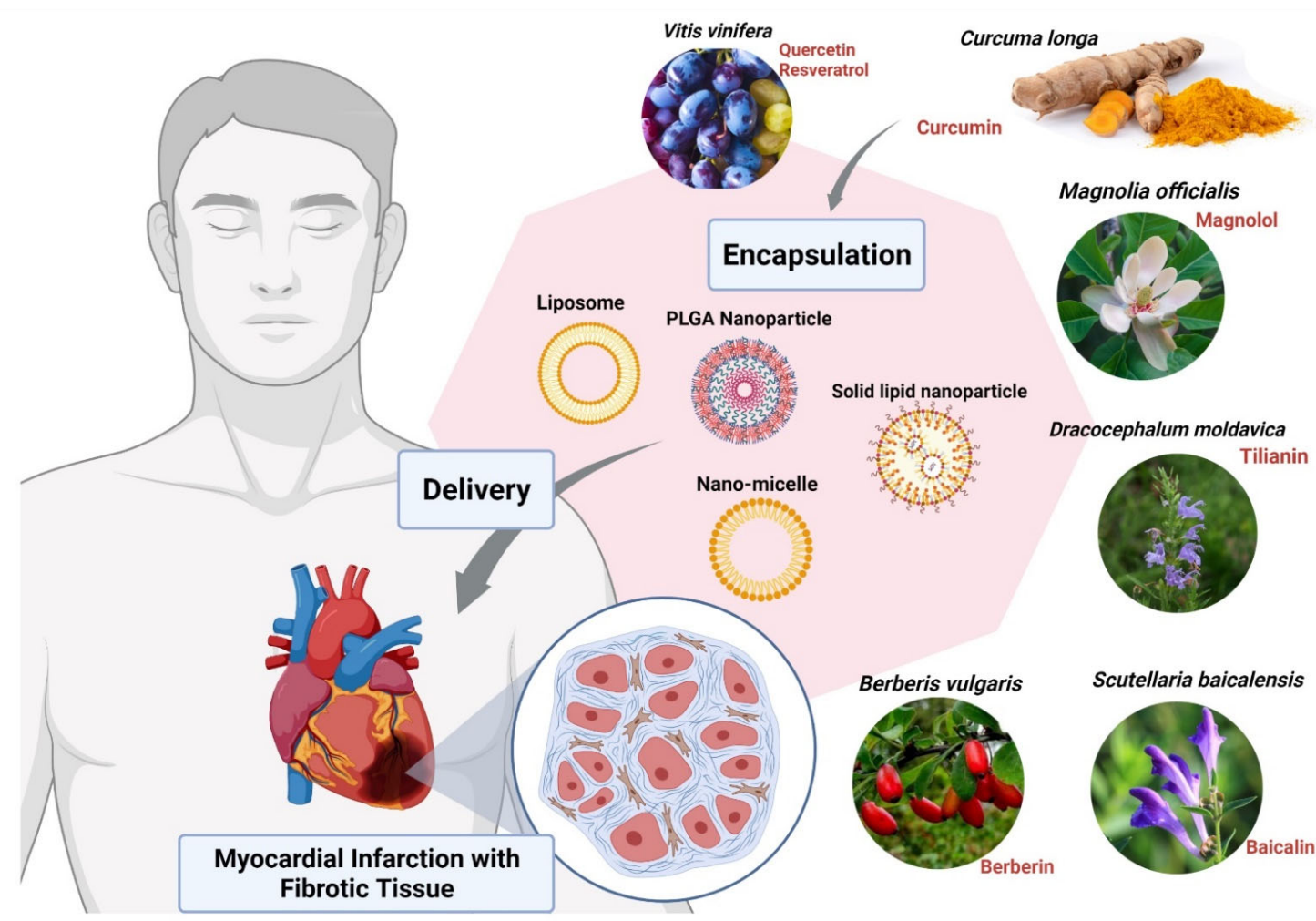

Figure 3. Encapsulation of bioactive compounds with nanoparticles from various herbal extracts to prevent cardiovascular disorders. Abbreviation: PLGA, poly (D,L-lactic acid-co-glycolic acid). The figure was made with www.biorender.com (access date: 12 January 2022). 


\subsection{Nano-Phytopharmaceuticals in Pulmonary Disorders}

Globally, at least two billion people get infections of the respiratory system, which causes disability, death and imposes an enormous health burden [108]. An estimated 65 million people have moderate to severe Chronic Obstructive Pulmonary Disease (COPD), which cause three million deaths every year [109]. About 334 million people suffer from asthma $[110,111]$. Acute lower respiratory tract infections are among the top three causes of death and disability. Influenza alone kills approximately 650,000 people annually [112]. Pulmonary disorders are characterized as progressive and incurable diseases, that comprise one of the five leading reasons for death around the world. The risk factors involved in the disease are smoking, permanent bronchoconstriction, alveolar destruction, and airway and pulmonary vascular remodeling [113].

Obstructive Lung Disease is characterized as airflow disturbances with consistent respiratory ailments. Patients having obstructive lung diseases present breathlessness, sputum production, and intolerance to exercise. Dyspnea may be considered a symptom of the early stages of the disease, whereas heart failure can be the symptom of severe and chronic disease [114]. In addition to chronic bronchitis and lung emphysema, it also affects various systems in the human body [115].

Tuberculosis, another respiratory disease, is one of the 10 leading causes of death from a single infectious agent. In 2019, around 1.4 million people died from tuberculosis (TB), and an estimated 10 million people became ill. Multidrug-resistant TB (MDR-TB) remains a public health crisis and a threat to security health [116]. In addition, more than 100 million people suffer from sleep-disordered breathing and millions live with pulmonary hypertension. More than 50 million people struggle with occupational lung diseases. The reason for pulmonary infections is the potential widespread pathogens in our environment and infections acquired from other infected individuals [117]. Nosocomial transmission primarily contributes to the pulmonary infections of multidrug-resistant (MDR) bacteria like cystic fibrosis [118] and bronchiectasis [119]. Intensive care units [120] are frequent sources of recurrent cross infection. The common nosocomial pneumonia with pathogens are Legionella, [121], Aspergillus [122] and mucormycosis [123].

Pathogens causing respiratory infections are either well adapted to the human body or cause little or no disease in animals. In addition, some pathogens, such as Mycobacterium tuberculosis and viruses producing IL-10, change their genetic system to evade the host immune system [124]. Another challenge of the respiratory infections is the development of drug-resistant pathogens, for example, pan-resistant Pseudomonas aeruginosa [125] and extensively drug-resistant $M$. tuberculosis [126]. Some new developments in drug-resistant pathogens, such as methicillin-resistant Staphylococcus aureus, are new threats in some regions [127]. Viruses are also developing resistance against many antiviral agents, for example, the neuraminidase inhibitor-resistant influenza virus [128]. The constant modification of viral genomes results in the antigenic drift and antigenic shift responsible for the development of resistant strains. New pathogens, like SARS, MERS and SARS-CoV-2, are serious threats to the world population [129]. The continuous use of antibiotics is creating a new niche for other pathogens, for example, bronchiectasis and cystic fibrosis, and non-tuberculous mycobacteria [130].

To curb the increasing threat of respiratory diseases, there is an immediate need to explore some alternatives to the use of antibiotics, and an ecofriendly, cost effective, efficacious and durable strategy to combat these global respiratory problems. Thus, the field of nanotechnology provides a promising technology against respiratory diseases. In the past, various studies have shown very effective and interesting results. In addition to their antiviral properties, the application of nanoparticles (NPs) provides a potential strategy to manage infections caused by multidrug-resistant organisms (MDROs) [131-133]. NPs exhibiting antibacterial activities can target multiple biomolecules and have the potential to reduce or eliminate the evolution of MDROs [134]. Plant extracts are complex mixtures that provide a rich arsenal of molecules, such as flavanones, flavones, flavonols and chalcones, fatty acids, amino acids, terpenoids, aldehydes, and alcohols [135], with high 
redox potential [136]. Furthermore, biogenic synthesis produces potential, stable, and better-defined materials $[137,138]$.

Silver nanoparticles (AgNPs) have shown broad applications in the medical system, such as anti-inflammatory, anti-angiogenesis, antiplatelet, antifungal, anticancer, and antibacterial activities [139-142]. Nowadays, AgNPs have been reported as biomedical therapeutic agents, such as wound dressings and long-term burn care products and antibacterial lotions [143]; They also exhibit antiviral activities against influenza A virus, hepatitis B virus, human parainfluenza virus, herpes simplex virus, and human immunodeficiency virus $[144,145]$. They prevent the anchoring and binding of the virus to the host and cell receptor, respectively, and hence they deactivate the virus by denaturing the surface.

AgNPs inhibit the binding of the virus by interacting with the glycoprotein (gp120) of the sulphur-bearing groups distributed in the lipid membrane of the virus [146]. In another study, the virus inactivation was observed when the nano-silver was combined with the nucleic acid of the virus and modified the structure of capsid and affected the replication [147]. Along with such surface modification, AgNPs also show synergistic antiviral activity. In one study, it was reported that curcumin, when used as both a reducing and stabilizing agent prevented viral replication, and blocked the budding of viruses [148]. Similarly, the AgNP surface, when modified through chemical methods with drugs like zanamivir, amantadine and oseltamivir, was able to interact with virus particles directly, which destroyed the virus and blocked its entry [149].

Du et al. showed the Ag2S NCs has excellent antiviral and immunomodulating activities against the porcine epidemic diarrhea virus (PEDV) [150]. Ag2S NCs also showed a comparable inhibitory effect of the virus on other RNA viruses, such as porcine reproductive and respiratory syndrome virus (PRRSV). Various reports on the use of natural products as reducing and capping agents for nanomaterial synthesis has been well documented [151,152]. Leaves of plants like Azadirachta indica [153], Ocimum tenuiforum [154], and Ficus benghalensis [155] have been used for the synthesis of AgNPs (Figure 4). The medicinal properties and broad-spectrum antimicrobial activities of Tulsi leaves were known for over a thousand years [156].

Gold nanoparticles (AuNPs) provide superior properties [157], and various methods for the preparation of gold nanoparticles have been well reported [139]. Compared to silver nanoparticles, AuNPs display better results in in vivo studies. AuNPs can interact with the haemagglutinin (HA) glycoprotein and can oxidize the disulfide bond, resulting in the inactivation of the virus [158]. Surface properties are useful in targeting the virus. The sulphonates are organic sulphates that were used to interact with the capsid proteins of the virus cell and prevent the HA activity [159]. In one study, it is reported that Brazilian Red Propolis (BRP), a product of bees, exhibits anti-inflammatory, anti-tumor, antioxidant, and antimicrobial activities [160]. It described the biosynthesis of AuNPs using BRP extract (AuNPextract) and its fractions (AuNPhexane, AuNPdichloromethane, AuNPethyl acetate) and evaluated their structural properties and their potential against micro-organisms and cancer cells.

Many drugs failed to treat viral infections, mainly due to drug release efficiency. To resolve this issue, mesoporous silicon nanoparticles are used as antiviral drug delivery carriers [161]. Compared to silver and gold nanoparticles, silicon nanomaterials are less cytotoxic and more biocompatible. The glycosaminoglycan (GAGs) mimetic-functionalized solid and mesoporous silica nanoparticles have shown antiviral activities that inhibit the entry of herpes simplex virus (HSV) type 1 and type 2 viruses into host cells [162].

In nanoscience, the carbon dots (CDs) also play an important role due to their unique properties. CDs prevent the viral infection as they have hydroxyl and carboxyl groups on their surfaces that interact with viral membranes [163]. To improve the activities of $\mathrm{CDs}$, antiviral agents like plant extracts are grafted on the surface that involves a two-step reaction. The functionalized antiviral agent shows the inhibition of the virus into the cell that has a broad-spectrum action for the enveloped and the non-enveloped viruses [164]. 


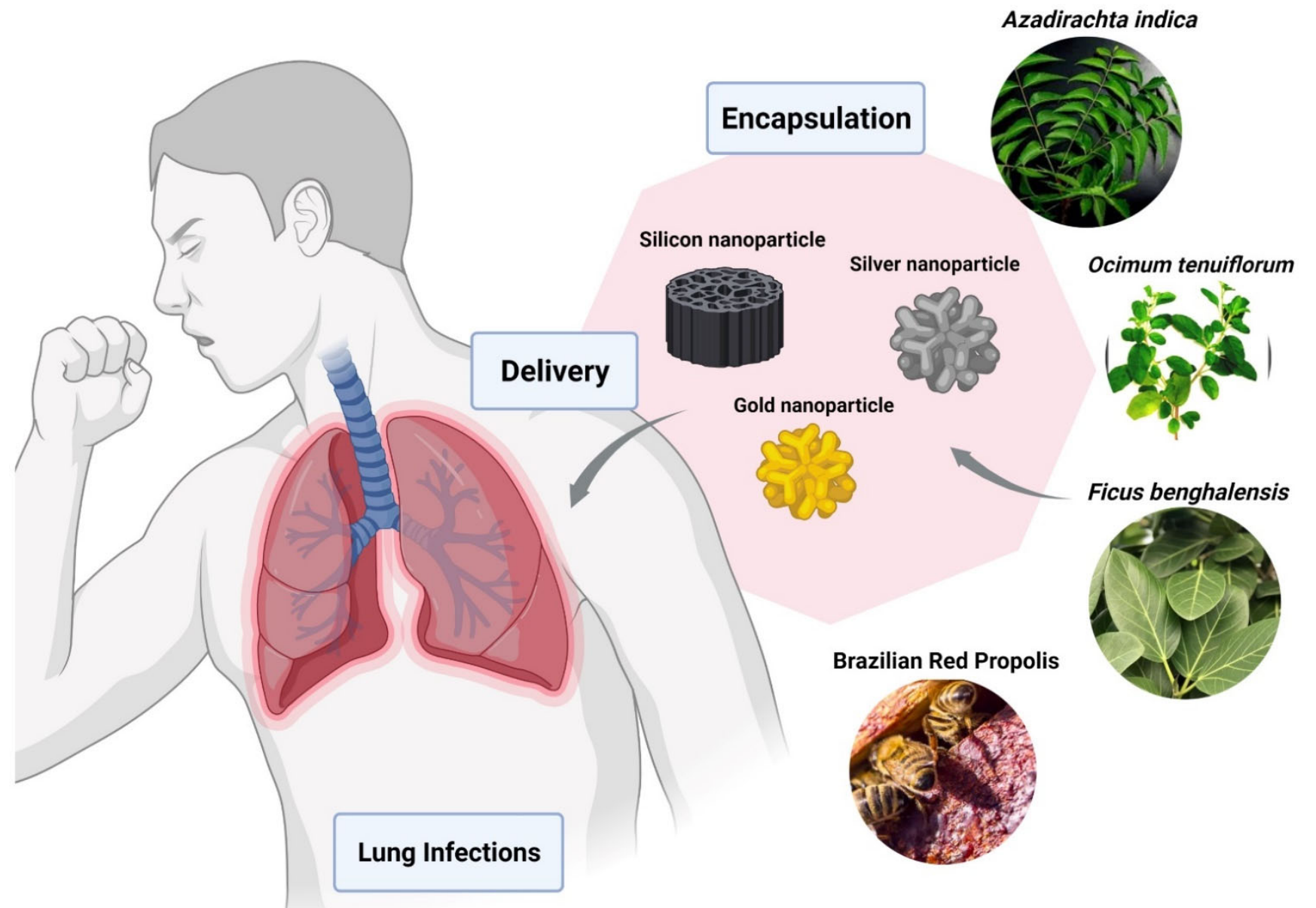

Figure 4. Encapsulation of bio-active compounds from various herbal extracts with silver, silicon, or gold nanoparticles to improve delivery in lungs and to prevent pulmonary disorders. The figure was made with www.biorender.com (access date: 12 January 2022).

Another important nanotechnology-based materials are based on graphene, (GO), which also have biomedical applications [165]. To prevent viral infection in the host cell, GO has been used with organic and metallic nanoparticles that show antiviral activities [166].

In one study, different nanocomposites of graphene oxide (GO) with Ag and iron oxide (IO) NPs were shown to exhibit both antimicrobial and magnetic properties. In another study, Ocsoy et al (2017) [167] reported that silver nanoparticles (Ag NPs)-decorated magnetic graphene oxide nanocomposites showed antimicrobial activities against Staphylococcus aureus (Gram+), Escherichia coli (Gram-) bacteria, and Candida albicans fungus.

Another material suitable for nanotechnology is selenium. In the in vivo study, selenium nanoparticles (SeNPs) showed antiviral efficiency [168]. Mainly, these nanoparticles depend on the quenching of free radicals in the host, and the prevention of the mitochondrial depolarization and apoptosis [168]. Zinc is another material that can be used in nanotechnology. In one study, ZnO-NPs, when inoculated with the virus, prevented cell adhesion from displaying the viral antigens to the T cells. The in vivo study showed that it has $90 \%$ antiviral activity and it mimics the couple cells [169]. In another study, ZnO-NPs and graphene carbon material showed antibacterial activities against Gram negative bacteria Escherichia coli [E. coli] and Gram-positive bacteria Staphylococcus aureus [170]. Graphene oxide-Ag nanoparticles formed from the extract of Pistacia atlantica leaves showed antimicrobial activities against S. aureus, S. saprophyticus, S. pyrogenes and B. Subtilis [171]. Calcium as a nanomaterial also has some unique features, and it can be used in nanotechnology. In one study, calcium phosphate nanoparticles (CaPNPs) showed antiviral activities [172]. 
The CaPNPs covalently modified with the alum and the two peptides generated efficient antibodies to block the cell from infection by the virus [173].

Self-assembling polypeptide nanoparticles that repetitively display a SARS B-cell epitope from the C-terminal heptad repeat of the virus' spike protein represent a promising platform for vaccine design [174]. It has also been reported that novel nanoparticle vaccine containing full spike protein of MERS CoV and SARS-CoV resulted in higher-titer neutralizing antibody in vaccinated mice [175]. The vaccination in combination with an adjuvant, matrix M1, boosted the neutralizing antibody titer [176].

Nanoparticles also have shown toxicity in lungs and other parts of the respiratory system, as observed in several preclinical and in vitro studies. Carbon black NPs showed increased release of pro-inflammatory cytokines in the alveoli that could potentially induce migration of macrophages in a lung cell line (type II alveolar epithelial cells) (in vitro) [177]. Another study showed $\mathrm{TiO}_{2} \mathrm{NPs}$ showed increased oxidative damage (increased nitric oxide and $\mathrm{H}_{2} \mathrm{O}_{2}$ levels), lipid peroxidation, and micronuclei formation in a human bronchial epithelial cell line [178]. Another study also reported that a daily dose of $40 \mathrm{mg} / \mathrm{kg}$ body weight of $\mathrm{TiO}_{2} \mathrm{NPs}$ over a period of three days increased serum albumin, alkaline phosphatase (ALP), acid phosphatase (ACP) levels, and pulmonary toxicity in mice [179]. Importantly, $\mathrm{pH}$ of the formulation, particle size, surface area, and aggregation of particles may play an important role in the pulmonary toxicity of $\mathrm{TiO}_{2} \mathrm{NPs}$ [179].

\subsection{Nano-Phytopharmaceuticals in Gastro-Intestinal Disorders}

Gastrointestinal disorders are recognized as an important health issue because of increasing number of individuals diagnosed with colorectal cancer, coeliac disease, and inflammatory bowel disease. Early diagnosis plays a vital role in survival, especially in colon cancer, which can be achieved with endoscopy or colonoscopy [180]. The gastrointestinal tract consists of a dynamic linkage where several layers frame a coordinated functional unit as a semipermeable ecosystem with multiple layers [181]. The association between host and gut microbiota is regulated by a mutual and complex symbiosis [182]. This association is continuously being tested with various factors, which may result in the destruction of the microbial community [182]. Dysbiosis, a disturbance in the composition of microbiota, has been related with severe complications of the gut, for example, in the pathogenesis of inflammatory bowel disease, irritable bowel syndrome and other GI disorders [183,184]. A dysregulated immune response to environmental factors leads to inflammatory disorders of the digestive system, such as inflammatory bowel syndrome, including ulcerative colitis or Crohn's disease [185]. Irritable bowel syndrome comprises the most recognized condition. In addition to other contributing factors, dysbiosis contributes as a major factor [186]. Similarly, diverticular disease is responsible for a significant burden in Western and developed nations, socially and economically. The pathophysiology of diverticular disease is not exactly known, though less intense inflammation and diversification of gut microbiota are considered to be the main factors associated with the disease. Gut microbiota specifically play a role in diverticula progression and in basic diverticular disease, which is defined as a disease with mild symptoms, for example pain in the abdomen or variations in bowel habits $[182,183]$.

There are numerous gastrointestinal diseases that can occur in different areas of the gastrointestinal tract [(GIT)], from the mouth to the anus [187]. Although the mouth is part of the GIT, mouth-related diseases are rarely considered as part of gastrointestinal diseases. The most common types of GIT-related diseases are Crohn's disease, ulcerative colitis, irritable bowel syndrome, and colorectal cancer. Their common symptoms include diarrhea, abdominal pain, stomach bloating, and gastrointestinal bleeding [188]. Apart from lifestyle and genetic factors, infectious agents such as parasites, virus, and bacteria are also known as the etiological agents for most of the gastrointestinal disorders. Interestingly, most gastrointestinal disorders can be cured with traditional or modern medicine. Phytotherapy based on herbal medicines has been one of the important resources to treat gastrointestinal 
disorders for many years. Their efficacies could be improved by using nanotechnology with lesser side effects.

Berberis vulgaris and Curcuma longa extracts encapsulated in cationic polymer EPO (Figure 5), demonstrated significant anti-parasitic activity against Entamoeba histolytica. Furthermore, $B$. vulgaris encapsulated within EPO showed $\mathrm{IC}_{50}$ of $26 \mathrm{ppm}$ in comparison with the free extract having $\mathrm{IC}_{50}$ of $34 \mu \mathrm{g} / \mathrm{mL}$. The $\mathrm{IC}_{50}$ of Curcuma longa loaded within $\mathrm{EPO}$ was found to be $19 \mathrm{ppm}$ in comparison with the free extract having $\mathrm{IC}_{50}$ of $38 \mu \mathrm{g} / \mathrm{mL}$ [187]. Another group of researchers used cerium oxide nanoparticles encapsulated with Nelumbo nucifera flower extract against the human colon cancer cell line (HCT 116), exhibited $\mathrm{IC}_{50}$ of $4.16 \mathrm{mg} / \mathrm{mL}$ [187]. Garcinia mangostana has been widely used for medical applications. G. mangostana extract loaded within ethylcellulose and methylcellulose nanoparticles proved a highly protective agent for stomach ulcers with a MIC value of $6.25 \mathrm{ug} / \mathrm{mL}$ against Helicobacter pylori, which is almost the same as metronidazole. A study done by Saravanakumar and team found that silver nanoparticles encapsulated with Toxicodendron vernicifluum extract were effective against enteropathogenic bacteria, E. coli and H. Pylori, with MIC $8.12 \mu \mathrm{g} / \mathrm{mL}$ and $18.14 \mu \mathrm{g} / \mathrm{mL}$. Acorus calamus Lim extract loaded within silver nanoparticles has shown significant inhibition in the formation of $H$. pylori at a concentration of $350 \mu \mathrm{g} / \mathrm{mL}$. Metallic nanoparticles demonstrated promising results in inhibition of enteropathogenic bacteria in various studies. Gold nanoparticles loaded with extracts of Tribulus terrestris showed effective activity against $H$. pylori in a size-dependent manner, with MIC of $16.75 \mu \mathrm{g} / \mathrm{mL}$ at $55 \mathrm{~nm}$ and MIC of $18 \mu \mathrm{g} / \mathrm{mL}$ at $7 \mathrm{~nm}$ size of gold nanoparticles, respectively [187](Figure 5; Table 3).

Table 3. Nano-phytopharmaceuticals for therapeutic applications in GI disorders.

\begin{tabular}{ccccc}
\hline Nanoformulation & Phyto-Pharmaceutical & Enteropathogen/GI Cell Lines; IC $50 /$ MIC & Reference \\
\hline Polymeric (EPO) & Berberis vulgaris & Entamoeba histolytica; 26 ppm & [187] \\
Polymeric (EPO) & Curcuma longa & Entamoeba histolytica; 19 $\mathrm{ppm}$ & [187] \\
Polymeric (Cerium oxide) & Nelumbo nucifera & Human colon cancer (HCT 116); 4.16 $\mu \mathrm{g} / \mathrm{mL}$ & {$[187]$} \\
Cellulose (Ethyl) & Garcinia mangostana & Helicobacter $p y l o r i ; 62.5 \mu \mathrm{g} / \mathrm{mL}$ & {$[187]$} \\
Metallic (Silver) & Toxicodendron vernicifluum & Helicobacter pylori; $18.14 \mu \mathrm{g} / \mathrm{mL}$ & {$[187]$} \\
Metallic (Silver) & Toxicodendron vernicifluum & E.coli; $8.12 \mu \mathrm{g} / \mathrm{mL}$ & {$[187]$} \\
Metallic (Gold) & Tribulus terrestris & Helicobacter pylori; $16.75 \mu \mathrm{g} / \mathrm{mL}$ & {$[187]$} \\
\hline
\end{tabular}

Apart from benefits, NPs showed adverse events, such as selenium and selenite nanoparticles in mice ( 2 or $4 \mathrm{mg} / \mathrm{kg}$ body weight daily) treated over a period of 15 days which showed more toxicity (growth suppression, increased liver toxicity, and reduced superoxide dismutase activity) in selenite NPs [189].

Nanotechnology is a vital tool for its applications in medical science, given that it is possible to obtain a variety of nanocarrier characteristics that include their constituents, size, shape, bioavailability, surface properties, and target specificity to achieve or enhance desirable pharmacological targets [187]. A number of strategies have been implemented to increase the drug-target specificity. Recently, several studies have reported the improved efficacy of herbal extracts for gastrointestinal disorders when associated with nanomaterials mainly due to oral absorption, greater stability, and simulated intestinal fluid [3,4]. Pure herbal medicines are often considered less effective in comparison due to their size and reduced intestinal absorption when administered orally. However, plant extracts loaded on nanoparticles are more stable in high protein environments and help to increase target specificity [4]. Solubility is always considered a major concern associated with plant extracts, which can be successfully upgraded using nanosystems [189]. These are the reasons behind a pharmacological loss associated with plant extracts and such problems can be overcome using novel drug delivery systems such as nanotechnology. The advantages of using these novel delivery systems include better absorption by smoothing diffusion through the epithelium, modification of pharmacokinetics, enhancement of intracellular penetration, and 
distribution with reduced toxicity, overcoming resistance and lowering cost. Nanoparticles are extremely stable in harsh conditions like sterilization temperatures [189].

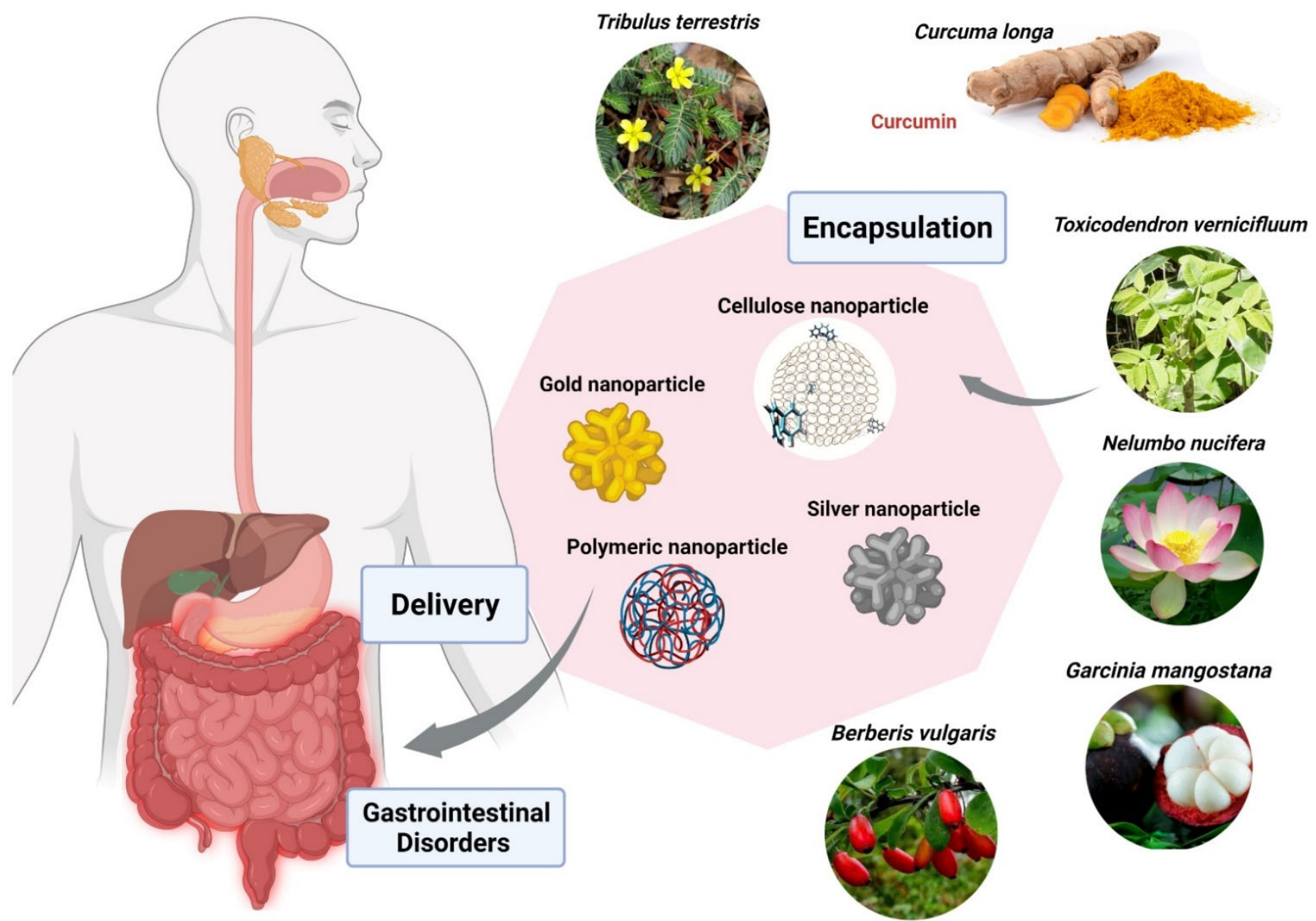

Figure 5. Encapsulation of bioactive compounds from various herbal extracts with silver, gold, cellulose, and polymeric nanoparticles to improve delivery in the gastrointestinal tract, and to prevent or cure various diseases. The figure was made with www.biorender.com (access date: 12 January 2022).

\section{Conclusions}

The role of nanotechnology has been evident in the field of public health. This review article highlights the role of nanotechnology applied to the treatment of various diseases. The use of nanomedicines can play a significant and promising role in the successful application of plant-based medicine to treat various diseases and thus improve patient health outcomes. Nanoparticles and their use in novel drug delivery systems may provide solutions to the problems faced by conventional or allopathic medicine, as well as the limitations of plant-based medicine delivery. Despite the great advent of nanotechnology, as explained in this review, there are some limitations mentioned below that should be developed and clarified in future research. For example, the unbalanced distribution of the inorganic parts of nanostructures in the brain may induce adverse effects. Additionally, the concentration of these nanomaterials in the brain may cause neurotoxicity, given their interference with mitochondrial activity, autophagy, apoptosis, and neuronal inflammation. Thus, in vitro and preclinical studies have shown that, by combining nanomaterials with plant-based drugs, a more adequate delivery to target cells or tissues is possible, increasing their effectiveness. However, the low reproducibility of in vitro and in vivo effects of many herbal medicines prevents these medications from reaching the clinical trial phases, so it 
will be necessary to develop concerted actions through in vitro and in vivo protocols that can be comparable. Therefore, preclinical pharmacodynamic and pharmacokinetic studies of the phytoconstituents involved are also important in view of their efficacy and safety. In addition, studies focused on systemic toxicity are still required to know its adverse effects in order to promote its future application. Future research studies must address describing critical process parameters, techniques, challenges, and solutions for the development of nano-phytopharmaceuticals.

Author Contributions: Conceptualization, V.N., M.R., P.W.; methodology, A.K.P., G.K.J., V.N.; validation, C.L.L., C.S.R., T.M., S.K., K.K.G., M.R., M.D., P.W., M.d.L.P.; investigation, T.M., M.N., J.K.P., P.W.; writing-original draft preparation, C.L.L., C.S.R., S.K., T.M., S.K., K.K.G.; writing-review and editing, V.N., M.d.L.P., A.K.P., M.D., M.N., M.R., J.K.P.; supervision, V.N., M.R., G.K.J. All authors have read and agreed to the published version of the manuscript.

Funding: M.d.L.P. thanks Project CICECO-Aveiro Institute of Materials, UIDB/50011/2020 and UIDP/50011/2020, national funds by FCT/MCTES. J.K.P. is grateful to the National Research Foundation of Korea [NRF] grant funded by the Korea government (MSIT) (No. 2020R1G1A1004667), the Republic of Korea for support.

Institutional Review Board Statement: Not applicable.

Informed Consent Statement: Not applicable.

Data Availability Statement: Not applicable.

Conflicts of Interest: The authors declare no conflict of interest.

\section{References}

1. Mobasser, S.; Firoozi, A.A. Review of nanotechnology applications in science and engineering. J. Civil. Eng. Urban. 2017, 64, 84-93.

2. Chen, G.; Roy, I.; Yang, C.; Prasad, P.N. Nanochemistry and nanomedicine for nanoparticle-based diagnostics and therapy. Chem. Rev. 2016, 116, 2826-2885. [CrossRef] [PubMed]

3. Morelli, L.; Gimondi, S.; Sevieri, M.; Salvioni, L.; Guizzetti, M.; Colzani, B.; Palugan, L.; Foppoli, A.; Talamini, L.; Morosi, L.; et al. Monitoring the fate of orally administered PLGA nanoformulation for local delivery of therapeutic drugs. Pharmaceutics 2019, 11, 658. [CrossRef]

4. Zhao, Q.; Luan, X.; Zheng, M.; Tian, X.-H.; Zhao, J.; Zhang, W.-D.; Ma, B.-L. Synergistic mechanisms of constituents in herbal extracts during intestinal absorption: Focus on natural occurring nanoparticles. Pharmaceutics 2020, 12, 128. [CrossRef] [PubMed]

5. Kumari, P.; Luqman, S.; Meena, A. Application of the combinatorial approaches of medicinal and aromatic plants with nanotechnology and its impacts on healthcare. DARU J. Pharm. Sci. 2019, 27, 475-489. [CrossRef] [PubMed]

6. Mitchell, M.J.; Billingsley, M.M.; Haley, R.M.; Wechsler, M.E.; Peppas, N.A.; Langer, R. Engineering precision nanoparticles for drug delivery. Nat. Rev. Drug Discov. 2021, 20, 101-124. [CrossRef]

7. Mishra, V.; Kesharwani, P.; Amin, M.C.M.; Iyer, A. (Eds.) Nanotechnology-Based Approaches for Targeting and Delivery of Drugs and Genes, 1st ed.; 2021; Available online: https:/ / www.elsevier.com/books/nanotechnology-based-approaches-for-targeting-anddelivery-of-drugs-and-genes/mishra/978-0-12-809717-5 (accessed on 20 August 2021).

8. Yetisgin, A.A.; Cetinel, S.; Zuvin, M.; Kosar, A.; Kutlu, O. Therapeutic nanoparticles and their targeted delivery applications. Molecules 2020, 25, 2193. [CrossRef]

9. Pelaz, B.; Alexiou, C.; Alvarez-Puebla, R.A.; Alves, F.; Andrews, A.M.; Ashraf, S.; Balogh, L.P.; Ballerini, L.; Bestetti, A.; Brendel, C.; et al. Diverse applications of nanomedicine. ACS Nano 2017, 11, 2313-2381. [CrossRef]

10. Prairna; Paramanya, A.; Sharma, S.; Bagdat, R.B.; Ali, A. Recent practices of medicinal and aromatic plants in nanotechnology. In Nanomaterials for Agriculture and Forestry Applications; Elsevier: Amsterdam, The Netherlands, 2020; pp. 435-467. [CrossRef]

11. Bernhoft, A. Bioactive compounds in plants -benefits and risks for man and snimals. The Norwegian Academy of Science and Letters, Oslo. 2010. Available online: https:/ / www.scirp.org/(S(351jmbntvnsjt1aadkposzje))/reference/ReferencesPapers.aspx? ReferenceID $=717353$ (accessed on 20 August 2021).

12. Bonifácio, B.V.; Silva, P.B.; Ramos, M.A.; Negri, K.M.; Bauab, T.M.; Chorilli, M. Nanotechnology-based drug delivery systems and herbal medicines: A review. Int. J. Nanomed. 2013, 9, 1-15. [CrossRef]

13. World Health Organization. WHO Global Report on Traditional and Complementary Medicine 2019 (Internet); World Health Organization: Geneva, Switzerland, 2019; pp. 1-228.

14. Yuan, H.; Ma, Q.; Ye, L.; Piao, G. The traditional medicine and modern medicine from natural products. Molecules 2016, $21,559$. [CrossRef]

15. Namdari, M.; Eatemadi, A.; Soleimaninejad, M.; Hammed, A.T. A brief review on the application of nanoparticle enclosed herbal medicine for the treatment of infective endocarditis. Biomed. Pharmacother. 2017, 87, 321-331. [CrossRef] 
16. Patra, J.K.; Das, G.; Fraceto, L.F.; Campos, E.V.R.; del Pilar Rodriguez-Torres, M.; Acosta-Torres, L.S.; Diaz-Torres, L.A.; Grillo, R.; Swamy, M.K.; Sharma, S.; et al. Nano based drug delivery systems: Recent developments and future prospects. J. Nanobiotechnol. 2018, 16, 71. [CrossRef] [PubMed]

17. Abbas, M. Potential role of nanoparticles in treating the accumulation of amyloid-beta peptide in Alzheimer's patients. Polymers 2021, 13, 1051. [CrossRef]

18. Zhai, K.; Siddiqui, M.; Abdellatif, B.; Liskova, A.; Kubatka, P.; Büsselberg, D. Natural compounds in glioblastoma therapy: Preclinical insights, mechanistic pathways, and outlook. Cancers 2021, 13, 2317. [CrossRef]

19. Khadka, B.; Lee, J.-Y.; Park, D.; Kim, K.-T.; Bae, J.-S. The role of natural compounds and their nanocarriers in the treatment of CNS inflammation. Biomolecules 2020, 10, 1401. [CrossRef] [PubMed]

20. Barchet, T.M.; Amiji, M.M. Challenges and opportunities in CNS delivery of therapeutics for neurodegenerative diseases. Expert Opin. Drug Deliv. 2009, 6, 211-225. [CrossRef]

21. Weintraub, D.; Comella, C.L.; Horn, S. Parkinson's disease-Part 1: Pathophysiology, symptoms, burden, diagnosis, and assessment. Am. J. Manag. Care 2008, 14, 40-48.

22. Walker, F.O. Huntington's disease. Lancet 2007, 369, 218-228. [CrossRef]

23. Imarisio, S.; Carmichael, J.; Korolchuk, V.; Chen, C.-W.; Saiki, S.; Rose, C.; Krishna, G.; Davies, J.E.; Ttofi, E.; Underwood, B.R.; et al. Huntington's disease: From pathology and genetics to potential therapies. Biochem. J. 2008, 412, 191-209. [CrossRef]

24. Vaquer-Alicea, J.; Diamond, M.I. Propagation of protein aggregation in neurodegenerative diseases. Annu. Rev. Biochem. 2019, 88, 785-810. [CrossRef]

25. Dugger, B.N.; Dickson, D.W. Pathology of neurodegenerative diseases. Cold Spring Harb. Perspect. Biol. 2017, 9, a028035. [CrossRef]

26. Gooch, C.L.; Pracht, E.; Borenstein, A.R. The burden of neurological disease in the United States: A summary report and call to action. Ann. Neurol. 2017, 81, 479-484. [CrossRef] [PubMed]

27. Abbott, N.J.; Rönnbäck, L.; Hansson, E. Astrocyte-endothelial interactions at the blood -Brain barrier. Nat. Rev. Neurosci. 2006, 7 , 41-53. [CrossRef] [PubMed]

28. Bergmann, S.; Lawler, S.E.; Qu, Y.; Fadzen, C.M.; Wolfe, J.M.; Regan, M.S.; Pentelute, B.L.; Agar, N.Y.R.; Cho, C.-F. Blood-Brain barrier organoids for investigating the permeability of CNS therapeutics. Nat. Protoc. 2018, 13, 2827-2843. [CrossRef] [PubMed]

29. Guerra, M.; Blázquez, J.L.; Rodríguez, E.M. Blood-brain barrier and foetal-onset hydrocephalus, with a view on potential novel treatments beyond managing CSF flow. Fluids Barriers CNS 2017, 14, 1-15. [CrossRef] [PubMed]

30. Dong, X. Current strategies for brain drug delivery. Theranostics 2018, 8, 1481-1493. [CrossRef] [PubMed]

31. Makkar, R.; Behl, T.; Bungau, S.; Zengin, G.; Mehta, V.; Kumar, A.; Uddin, S.; Ashraf, G.M.; Abdel-Daim, M.M.; Arora, S.; et al. Nutraceuticals in neurological disorders. Int. J. Mol. Sci. 2020, 21, 4424. [CrossRef]

32. Uddin, S.; Hossain, F.; Al Mamun, A.; Shah, M.A.; Hasana, S.; Bulbul, I.J.; Sarwar, S.; Mansouri, R.A.; Ashraf, G.M.; Rauf, A.; et al. Exploring the multimodal role of phytochemicals in the modulation of cellular signaling pathways to combat age-related neurodegeneration. Sci. Total Environ. 2020, 725, 138313. [CrossRef]

33. Zhu, F.-D.; Hu, Y.-J.; Yu, L.; Zhou, X.-G.; Wu, J.-M.; Tang, Y.; Qin, D.-L.; Fan, Q.-Z.; Wu, A.-G. Nanoparticles: A hope for the treatment of inflammation in CNS. Front. Pharmacol. 2021, 12, 683935. [CrossRef]

34. Schmitt, C.; Lechanteur, A.; Cossais, F.; Bellefroid, C.; Arnold, P.; Lucius, R.; Held-Feindt, J.; Piel, G.; Hattermann, K. Liposomal encapsulated curcumin effectively attenuates neuroinflammatory and reactive astrogliosis reactions in glia cvells and organotypic brain slices. Int. J. Nanomed. 2020, ume 15, 3649-3667. [CrossRef]

35. Alphandéry, E. Nano-therapies for glioblastoma treatment. Cancers 2020, 12, 242. [CrossRef] [PubMed]

36. Zhai, K.; Brockmüller, A.; Kubatka, P.; Shakibaei, M.; Büsselberg, D. Curcumin's beneficial effects on neuroblastoma: Mechanisms, challenges, and potential solutions. Biomolecules 2020, 10, 1469. [CrossRef]

37. Dibaei, M.; Rouini, M.-R.; Sheikholeslami, B.; Gholami, M.; Dinarvand, R. The effect of surface treatment on the brain delivery of curcumin nanosuspension: In vitro and in vivo studies. Int. J. Nanomed. 2019, ume 14, 5477-5490. [CrossRef]

38. Kalashnikova, I.; Mazar, J.; Neal, C.J.; Rosado, A.L.; Das, S.; Westmoreland, T.J.; Seal, S. Nanoparticle delivery of curcumin induces cellular hypoxia and ROS-mediated apoptosis: Via modulation of Bcl-2/Bax in human neuroblastoma. Nanoscale 2017, 9 , 10375-10387. [CrossRef]

39. Montalbán, M.G.; Coburn, J.M.; Lozano-Pérez, A.A.; Cenis, J.L.; Víllora, G.; Kaplan, D.L. Production of curcumin-loaded silk fibroin nanoparticles for cancer therapy. Nanomaterials 2018, 8, 126. [CrossRef] [PubMed]

40. Baspinar, Y.; Üstündas, M.; Bayraktar, O.; Sezgin, C. Curcumin and piperine loaded zein-chitosan nanoparticles: Development and in-vitro characterisation. Saudi Pharm. J. 2018, 26, 323-334. [CrossRef] [PubMed]

41. Chen, S.; McClements, D.J.; Jian, L.; Han, Y.; Dai, L.; Mao, L.; Gao, Y. Core-shell biopolymer nanoparticles for co-delivery of curcumin and piperine: Sequential electrostatic deposition of hyaluronic acid and chitosan shells on the zein core. ACS Appl. Mater. Interfaces 2019, 11, 38103-38115. [CrossRef]

42. Ege, D. Action mechanisms of curcumin in Alzheimer's disease and its brain targeted delivery. Materials 2021, 14, 3332. [CrossRef] [PubMed]

43. Sadegh Malvajerd, S.; Azadi, A.; Izadi, Z.; Kurd, M.; Dara, T.; Dibaei, M.; Zadeh, M.S.; Javar, H.A.; Hamidi, M. Brain delivery of curcumin using solid lipid nanoparticles and nanostructured lipid carriers: Preparation, optimization, and pharmacokinetic evaluation. ACS Chem. Neurosci. 2019, 10, 728-739. [CrossRef] 
44. Giacomeli, R.; Izoton, J.C.; dos Santos, R.B.; Boeira, S.P.; Jesse, C.R.; Haas, S.E. Neuroprotective effects of curcumin lipidcore nanocapsules in a model Alzheimer's disease induced by $\beta$-amyloid 1-42 peptide in aged female mice. Brain Res. 2019, 1721, 146325. [CrossRef]

45. Nakama, K.A.; dos Santos, R.B.; Silva, C.E.D.R.; Izoton, J.C.; Savall, A.S.P.; Gutirrez, M.E.Z.; Roman, S.S.; Luchese, C.; Pinton, S.; Haas, S.E. Establishment of analytical method for quantification of anti-inflammatory agents co-nanoencapsulated and its application to physicochemical development and characterization of lipid-core nanocapsules. Arab. J. Chem. 2020, 13, 2456-2469. [CrossRef]

46. Ganesan, P.; Kim, B.; Ramalingam, P.; Karthivashan, G.; Revuri, V.; Park, S.; Kim, J.S.; Ko, Y.T.; Choi, D.-K.; Ramalaingam, P. Antineuroinflammatory activities and neurotoxicological assessment of curcumin loaded solid lipid nanoparticles on LPSstimulated BV-2 microglia cell models. Molecules 2019, 24, 1170. [CrossRef]

47. Maiti, P.; Paladugu, L.; Dunbar, G.L. Solid lipid curcumin particles provide greater anti-amyloid, anti-inflammatory and neuroprotective effects than curcumin in the 5xFAD mouse model of Alzheimer's disease. BMC Neurosci. 2018, 19, 1-18. [CrossRef]

48. Jeon, S.G.; Cha, M.-Y.; Kim, J.-I.; Hwang, T.W.; Kim, K.A.; Kim, T.H.; Song, K.C.; Kim, J.-J.; Moon, M. Vitamin D-binding protein-loaded PLGA nanoparticles suppress Alzheimer's disease-related pathology in 5XFAD mice. Nanomed. Nanotechnol. Biol. Med. 2019, 17, 297-307. [CrossRef]

49. Huang, N.; Lu, S.; Liu, X.-G.; Zhu, J.; Wang, Y.-J.; Liu, R.-T. PLGA nanoparticles modified with a BBB-penetrating peptide co-delivering $A \beta$ generation inhibitor and curcumin attenuate memory deficits and neuropathology in Alzheimer's disease mice. Oncotarget 2017, 8, 81001-81013. [CrossRef]

50. Huo, X.; Zhang, Y.; Jin, X.; Li, Y.; Zhang, L. A novel synthesis of selenium nanoparticles encapsulated PLGA nanospheres with curcumin molecules for the inhibition of amyloid $\beta$ aggregation in Alzheimer's disease. J. Photochem. Photobiol. B Biol. 2019, 190, 98-102. [CrossRef]

51. Sathya, S.; Shanmuganathan, B.; Balasubramaniam, B.; Balamurugan, K.; Devi, K.P. Phytol loaded PLGA nanoparticles regulate the expression of Alzheimer's related genes and neuronal apoptosis against amyloid- $\beta$ induced toxicity in Neuro-2a cells and transgenic Caenorhabditis elegans. Food Chem. Toxicol. 2019, 136, 110962. [CrossRef]

52. Zhang, L.; Yang, S.; Wong, L.R.; Xie, H.; Ho, P.C.L. In vitro and in vivo comparison of curcumin-encapsulated chitosan-coated poly (lactic- co-glycolic acid) nanoparticles and curcumin/Hydroxypropyl- $\beta$-Cyclodextrin inclusion complexes administered intranasally as therapeutic strategies for Alzheimer's diseas. Mol. Pharm. 2020, 17, 4256-4269. [CrossRef]

53. Cheng, K.K.; Chan, P.S.; Fan, S.; Kwan, S.M.; Yeung, K.L.; Wang, Y.-X.; Chow, A.H.L.; Wu, E.X.; Baum, L. Curcumin-conjugated magnetic nanoparticles for detecting amyloid plaques in Alzheimer's disease mice using magnetic resonance imaging (MRI). Biomaterials 2015, 44, 155-172. [CrossRef]

54. Huang, X.; Li, N.; Pu, Y.; Zhang, T.; Wang, B. Neuroprotective effects of Ginseng phytochemicals: Recent perspectives. Molecules 2019, 24, 2939. [CrossRef]

55. Sairazi, N.S.M.; Sirajudeen, K.N.S. Natural products and their bioactive compounds: Neuroprotective potentials against neurodegenerative diseases. Evid. Based Complement. Altern. Med. 2020, 2020, 1-30. [CrossRef] [PubMed]

56. Rajabian, A.; Rameshrad, M.; Hosseinzadeh, H. Therapeutic potential of Panax ginseng and its constituents, ginsenosides and gintonin, in neurological and neurodegenerative disorders: A patent review. Expert Opin. Ther. Patents 2019, 29, 55-72. [CrossRef] [PubMed]

57. Razgonova, M.; Veselov, V.; Zakharenko, A.M.; Golokhvast, K.; Nosyrev, A.E.; Cravotto, G.; Tsatsakis, A.; Spandidos, D. Panax ginseng components and the pathogenesis of Alzheimer's disease (Review). Mol. Med. Rep. 2019, 19, 2975-2998. [CrossRef] [PubMed]

58. Aalinkeel, R.; Kutscher, H.L.; Singh, A.; Cwiklinski, K.; Khechen, N.; Schwartz, S.A.; Prasad, P.N.; Mahajan, S.D. Neuroprotective effects of a biodegradable poly(lactic-co-glycolic acid)-ginsenoside $\operatorname{Rg} 3$ nanoformulation: A potential nanotherapy for Alzheimer's disease? J. Drug Target. 2017, 26, 182-193. [CrossRef] [PubMed]

59. Oh, J.; Kim, J.-S. Compound K derived from Ginseng: Neuroprotection and cognitive improvement. Food Funct. 2016, 7, 4506-4515. [CrossRef]

60. Sharma, A.; Lee, H.-J. Ginsenoside Compound K: Insights into recent studies on pharmacokinetics and health-promoting activities. Biomolecules 2020, 10, 1028. [CrossRef] [PubMed]

61. Li, J.; Huang, Q.; Chen, J.; Qi, H.; Liu, J.; Chen, Z.; Zhao, D.; Wang, Z.; Li, X. Neuroprotective potentials of Panax ginseng against Alzheimer's disease: A review of preclinical and clinical evidences. Front. Pharmacol. 2021, 12, 688490. [CrossRef]

62. Kim, J.W.; Cho, C.H.; Hwang, Y.-G.; Park, W.J.; Kang, H.; Kim, D.-O. Protective effects of red ginseng treated with gold nanoparticles against $\mathrm{H}_{2} \mathrm{O}_{2}$-induced oxidative stress in neuronal PC-12 cells. Korean J. Food Sci. Technol. 2017, 49, $222-227$. [CrossRef]

63. Yang, L.; Li, C.-L.; Tsai, T.-H. Preclinical herb-drug pharmacokinetic interaction of Panax ginseng extract and selegiline in freely moving rats. ACS Omega 2020, 5, 4682-4688. [CrossRef] [PubMed]

64. Singh, P.; Singh, H.; Ahn, S.; Castro-Aceituno, V.; Jiménez, Z.; Simu, S.Y.; Kim, Y.J.; Yang, D.C. Pharmacological importance, characterization and applications of gold and silver nanoparticles synthesized by Panax ginseng fresh leaves. Artif. Cells, Nanomed. Biotechnol. 2017, 45, 1415-1424. [CrossRef] [PubMed] 
65. Mathiyalagan, R.; Yang, D.C. Ginseng nanoparticles: A budding tool for cancer treatment. Nanomedicine 2017, 12, 1091-1094. [CrossRef] [PubMed]

66. Zhu, Y.; Liang, J.; Gao, C.; Wang, A.; Xia, J.; Hong, C.; Zhong, Z.; Zuo, Z.; Kim, J.; Ren, H.; et al. Multifunctional ginsenoside Rg3-based liposomes for glioma targeting therapy. J. Control. Release 2021, 330, 641-657. [CrossRef] [PubMed]

67. Dai, L.; Zhu, W.; Si, C.; Lei, J. Nano-ginseng" for enhanced cytotoxicity against cancer cells. Int. J. Mol. Sci. 2018, 19, 627. [CrossRef]

68. Zhang, J.; Zheng, Y.; Luo, Y.; Du, Y.; Zhang, X.; Fu, J. Curcumin inhibits LPS-induced neuroinflammation by promoting microglial M2 polarization via TREM2/ TLR4/ NF-кB pathways in BV2 cells. Mol Immunol. 2019, 116, 29-37. [CrossRef] [PubMed]

69. Pattan, G.; Kaul, G. Health hazards associated with nanomaterials. Toxicol. Ind. Heal. 2012, 30, 499-519. [CrossRef]

70. Wang, J.; Chen, C.; Liu, Y.; Jiao, F.; Li, W.; Lao, F.; Li, Y.-F.; Li, B.; Ge, C.; Zhou, G. Potential neurological lesion after nasal instillation of $\mathrm{TiO}_{2}$ nanoparticles in the anatase and rutile crystal phases. Toxicol. Lett. 2008, 183, 72-80. [CrossRef]

71. Pisanic, T.R.; Blackwell, J.D.; Shubayev, V.I.; Fiñones, R.R.; Jin, S. Nanotoxicity of iron oxide nanoparticle internalization in growing neurons. Biomaterials 2007, 28, 2572-2581. [CrossRef]

72. Zhao, J.; Xu, L.; Zhang, T.; Ren, G.; Yang, Z. Influences of nanoparticle zinc oxide on acutely isolated rat hippocampal CA3 pyramidal neurons. NeuroToxicology 2009, 30, 220-230. [CrossRef]

73. Cha, K.E.; Myung, H. Cytotoxic effects of nanoparticles assessed in vitro and in vivo. J. Microbiol. Biotechnol. 2007, 17, 1573-1578 [PubMed]

74. WHO. Cardiovascular diseases (CVDs). Available online: https://www.who.int/en/news-room/fact-sheets/detail/ cardiovascular-diseases-(cvds) (accessed on 16 May 2021).

75. Rastogi, S.; Pandey, M.M.; Rawat, A. Traditional herbs: A remedy for cardiovascular disorders. Phytomedicine 2016, 23, 1082-1089. [CrossRef]

76. Deb, S.; Dasgupta, A. A study on risk factors of cardiovascular diseases in an urban health center of Kolkata. Indian J. Community Med. 2008, 33, 271-275. [CrossRef] [PubMed]

77. Ritchey, M.D.; Wall, H.K.; George, M.G.; Wright, J.S. US trends in premature heart disease mortality over the past 50 years: Where do we go from here? Trends Cardiovasc. Med. 2020, 30, 364-374. [CrossRef] [PubMed]

78. Olvera, L.E.; Ballard, B.D.; Jan, A. Cardiovascular disease. In StatPearls; StatPearls Publishing: Treasure Island, FL, USA, 2021. Available online: https:/ / www.ncbi.nlm.nih.gov /books/NBK535419/ (accessed on 6 January 2022).

79. Krishnamoorthy, A.; Greiner, M.A.; Bertoni, A.; Eapen, Z.J.; O’Brien, E.C.; Curtis, L.H.; Hernandez, A.F.; Mentz, R.J. The obesity and heart failure epidemics among African Americans: Insights from the Jackson heart study. J. Card. Fail. 2016, 22, 589-597. [CrossRef] [PubMed]

80. Thiriet, M. Cardiovascular disease: An introduction. Vasculopathies 2018, 8, 1-90. [CrossRef]

81. American Heart Association. Cardiac Medications; AHA: Dallas, TX, USA; Available online: https://www.heart.org/en/healthtopics/heart-attack/treatment-of-a-heart-attack/cardiac-medications (accessed on 2 July 2020).

82. Rossello, X.; Pocock, S.J.; Julian, D.G. Long-term use of cardiovascular drugs challenges for research and for patient care. J Am Coll Cardiol. 2015, 66, 1273-1285. [CrossRef] [PubMed]

83. Van Der Laan, D.M.; Elders, P.J.M.; Boons, C.C.L.M.; Nijpels, G.; Krska, J.; Hugtenburg, J.G. The impact of cardiovascular medication use on patients' daily lives: A cross-sectional study. Int. J. Clin. Pharm. 2018, 40, 412-420. [CrossRef]

84. Chronic kidney disease in the United States. 2021. Available online: https://www.cdc.gov/kidneydisease/publicationsresources/ckd-national-facts.html (accessed on 2 June 2021).

85. Hesari, M.; Mohammadi, P.; Khademi, F.; Shackebaei, D.; Momtaz, S.; Moasefi, N.; Farzaei, M.H.; Abdollahi, M. Current Advances in the use of nanophytomedicine therapies for human cardiovascular diseases. Int. J. Nanomed. 2021, 16, 3293-3315. [CrossRef]

86. Owen, A.; Dufès, C.; Moscatelli, D.; Mayes, E.; Lovell, J.F.; Katti, K.V.; Sokolov, K.; Mazza, M.; Fontaine, O.; Rannard, S.; et al. The application of nanotechnology in medicine: Treatment and diagnostics. Nanomedicine 2014, 9, 1291-1294. [CrossRef]

87. Wang, D.K.; Rahimi, M.; Filgueira, C.S. Nanotechnology applications for cardiovascular disease treatment: Current and future perspectives. Nanomed. Nanotechnol. Biol. Med. 2021, 34, 102387. [CrossRef]

88. Gera, M.; Sharma, N.; Ghosh, M.; Huynh, D.L.; Lee, S.J.; Min, T.; Kwon, T.; Jeong, D.K. Nanoformulations of curcumin: An emerging paradigm for improved remedial application. Oncotarget 2017, 8, 66680-66698. [CrossRef] [PubMed]

89. Lozano, O.; Lázaro-Alfaro, A.; Silva-Platas, C.; Oropeza-Almazán, Y.; Torres-Quintanilla, A.; Bernal-Ramirez, J.; Figueiredo, H.; García-Rivas, G. Nanoencapsulated quercetin improves cardioprotection during hypoxia-reoxygenation injury through preservation of mitochondrial function. Oxidative Med. Cell. Longev. 2019, 2019, 1-14. [CrossRef] [PubMed]

90. Summerlin, N.; Soo, E.; Thakur, S.; Qu, Z.; Jambhrunkar, S.; Popat, A. Resveratrol nanoformulations: Challenges and opportunities. Int. J. Pharm. 2015, 479, 282-290. [CrossRef]

91. Shahraki, A.; Bahadorikhalili, S.; Hashemzaei, M.; Hajinezhad, M.; Afsharimoghaddam, A.; Sarani, F.; Tajrobekar, O. Resveratrol nano-capsule as an efficient tool for blood pressure regulation: A study on metabolic syndrome induced mice. Biosci Biotechnol. Res Commun. 2017, 10, 623-630. [CrossRef]

92. Shen, P.; Zhang, Z.; He, Y.; Gu, C.; Zhu, K.; Li, S.; Li, Y.; Lu, X.; Liu, J.; Zhang, N.; et al. Magnolol treatment attenuates dextran sulphate sodium-induced murine experimental colitis by regulating inflammation and mucosal damage. Life Sci. 2018, 196, 69-76. [CrossRef] [PubMed] 
93. Stefanache, A.; Ignat, M.; Peptu, C.A.; Diaconu, A.; Stoleriu, I.; Ochiuz, L. Development of a prolonged-release drug delivery system with magnolol loaded in amino-functionalized mesoporous silica. Appl. Sci. 2017, 7, 237. [CrossRef]

94. Sheng, Y.-L.; Xu, J.-H.; Shi, C.-H.; Li, W.; Xu, H.-Y.; Li, N.; Zhao, Y.-Q.; Zhang, X.-R. UPLC-MS/MS-ESI assay for simultaneous determination of magnolol and honokiol in rat plasma: Application to pharmacokinetic study after administration emulsion of the isomer. J. Ethnopharmacol. 2014, 155, 1568-1574. [CrossRef]

95. Wang, Y.-J.; Chien, Y.-C.; Wu, C.-H.; Liu, D.-M. Magnolol-loaded core-shell hydrogel nanoparticles: Drug release, intracellular uptake, and controlled cytotoxicity for the inhibition of migration of vascular Ssooth muscle cells. Mol. Pharm. 2011, 8, 2339-2349. [CrossRef]

96. Xia, L.-M.; Luo, M.-H. Study progress of berberine for treating cardiovascular disease. Chronic Dis. Transl. Med. 2015, 1, $231-235$. [CrossRef]

97. Wang, Y.; Wang, Y.; Wang, X.; Hu, P. Tilianin-loaded reactive oxygen species-scavenging nano-micelles protect H9c2 cardiomyocyte against hypoxia/reoxygenation-induced injury. J. Cardiovasc. Pharmacol. 2018, 72, 32-39. [CrossRef]

98. Wang, B.; Feng, W.-Y.; Wang, T.-C.; Jia, G.; Wang, M.; Shi, J.-W.; Zhang, F.; Zhao, Y.-L.; Chai, Z.-F. Acute toxicity of nano- and micro-scale zinc powder in healthy adult mice. Toxicol. Lett. 2006, 161, 115-123. [CrossRef]

99. Zhang, J.; Wang, H.; Yan, X.; Zhang, L. Comparison of short-term toxicity between Nano-Se and selenite in mice. Life Sci. 2005, 76, 1099-1109. [CrossRef] [PubMed]

100. Zhang, S.; Wang, J.; Pan, J. Baicalin-loaded PEGylated lipid nanoparticles: Characterization, pharmacokinetics, and protective effects on acute myocardial ischemia in rats. Drug Deliv. 2016, 23, 3696-3703. [CrossRef]

101. Xin, L.; Gao, J.; Lin, H.; Qu, Y.; Shang, C.; Wang, Y.; Lu, Y.; Cui, X. Regulatory mechanisms of baicalin in cardiovascular diseases: A review. Front. Pharmacol. 2020, 11, 583200. [CrossRef]

102. Salehi, B.; Prado-Audelo, D.; María, L.; Cortés, H.; Leyva-Gómez, G.; Stojanović-Radić, Z.; Singh, Y.D.; Patra, J.K.; Das, G.; Martins, N.; et al. Therapeutic applications of curcumin nanomedicine formulations in cardiovascular diseases. J. Clin. Med. 2020, 9, 746. [CrossRef]

103. Bonnefont-Rousselot, D. Resveratrol and Cardiovascular Diseases. Nutrients 2016, 8, 250. [CrossRef]

104. Duan, Y.; Dhar, A.; Patel, C.; Khimani, M.; Neogi, S.; Sharma, P.; Kumar, N.S.; Vekariya, R.L. A brief review on solid lipid nanoparticles: Part and parcel of contemporary drug delivery systems. RSC Adv. 2020, 10, 26777-26791. [CrossRef]

105. Lin, Y.; Li, Y.; Zeng, Y.; Tian, B.; Qu, X.; Yuan, Q.; Song, Y. Pharmacology, toxicity, bioavailability, and formulation of magnolol: An update. Front. Pharmacol. 2021, 12, 632767. [CrossRef]

106. Chen, C.Y.-C.; Wu, C.-H. Magnolol encapsulated by liposome in inhibiting smooth muscle cell proliferation. J. Chin. Chem. Soc. 2008, 55, 517-521. [CrossRef]

107. Duong, T.; Isomäki, A.; Paaver, U.; Laidmäe, I.; Tõnisoo, A.; Yen, T.; Kogermann, K.; Raal, A.; Heinämäki, J.; Pham, T.-M.-H Nanoformulation and evaluation of oral berberine-loaded liposomes. Molecules 2021, 26, 2591. [CrossRef]

108. GBD 2015 Mortality and causes of death collaborators. Global, regional, and national life expectancy, all-cause mortality, and cause-specific mortality for 249 causes of death, 1980-2015: A systematic analysis for the Global Burden of Disease Study 2015. Lancet 2016, 388, 1459-1544. [CrossRef]

109. Burney, P.G.; Patel, J.; Newson, R.; Minelli, C.; Naghavi, M. Global and regional trends in COPD mortality, 1990-2010. Eur. Respir. J. 2015, 45, 1239-1247. [CrossRef]

110. Pearce, N.; Aït-Khaled, N.; Beasley, R.; Mallol, J.; Keil, U.; Mitchell, E.; Robertson, C.; the ISAAC Phase Three Study Group. Worldwide trends in the prevalence of asthma symptoms: Phase III of the international study of asthma and allergies in childhood (ISAAC). Thorax 2007, 62, 758-766. [CrossRef]

111. Global asthma network. The Global Asthma Report 2014; Global Asthma Network: Auckland, New Zealand, 2014; Available online: http://globalasthmareport.org/2014/Global_Asthma_Report_2014.pdf (accessed on 4 January 2022).

112. World Health Organization (WHO). Up to 650,000 People die of respiratory diseases linked to seasonal Ffu each year. Available online: https: / / www.who.int/news/item/13-12-2017-up-to-650-000-people-die-of-respiratory-diseases-linked-to-seasonalflu-each-year (accessed on 2 April 2021).

113. WHO. Global Tuberculosis Report 2019; WHO: Geneva, Switzerland, 2019; Available online: https://www.who.int/publications/i/ item/9789241565714 (accessed on 4 January 2022).

114. Vestbo, J.; Hurd, S.S.; Agustí, A.G.; Jones, P.W.; Vogelmeier, C.; Anzueto, A.; Barnes, P.J.; Fabbri, L.M.; Martinez, F.J.; Nishimura, M.; et al. Global strategy for the diagnosis, management, and prevention of chronic obstructive pulmonary disease GOLD executive summary. Am. J. Respir. Crit. Care Med. 2013, 187, 347-365. [CrossRef] [PubMed]

115. Mei, D.; Tan, W.S.D.; Tay, Y.; Mukhopadhyay, A.; Wong, W.F. Therapeutic RNA strategies for chronic obstructive pulmonary disease. Trends Pharmacol. Sci. 2020, 41, 475-486. [CrossRef] [PubMed]

116. Gredic, M.; Blanco, I.; Kovacs, G.; Helyes, Z.; Ferdinandy, P.; Olschewski, H.; Barberà, J.A.; Weissmann, N. Pulmonary hypertension in chronic obstructive pulmonary disease. Br. J. Pharmacol. 2021, 178, 132-151. [CrossRef]

117. Lo, J.Y.; Tsang, T.H.; Leung, Y.-H.; Yeung, E.Y.; Wu, T.; Lim, W.W. Respiratory infections during SARS outbreak, Hong Kong, 2003. Emerg. Infect. Dis. 2005, 11, 1738-1741. [CrossRef]

118. Panagea, S.; Winstanley, C.; Walshaw, M.; Ledson, M.; Hart, C. Environmental contamination with an epidemic strain of Pseudomonas aeruginosa in a Liverpool cystic fibrosis centre, and study of its survival on dry surfaces. J. Hosp. Infect. 2005, 59, 102-107. [CrossRef] [PubMed] 
119. Robinson, P.; Carzino, R.; Armstrong, D.; Olinsky, A. Pseudomonas cross-infection from cystic fibrosis patients to non-cystic fibrosis patients: Implications for inpatient care of respiratory patients. J. Clin. Microbiol. 2003, 41, 5741. [CrossRef]

120. Bloemendaal, A.L.A.; Fluit, A.C.; Jansen, W.M.T.; Vriens, M.R.; Ferry, T.; Argaud, L.; Amorim, J.M.; Resende, A.C.; Pascual, A.; López-Cerero, L.; et al. Acquisition and cross-transmission of Staphylococcus aureus in European intensive care units. Infect. Control. Hosp. Epidemiol. 2009, 30, 117-124. [CrossRef]

121. Boccia, S.; Laurenti, P.; Borella, P.; Moscato, U.; Capalbo, G.; Cambieri, A.; Amore, R.; Quaranta, G.; Boninti, F.; Orsini, M.; et al. Prospective 3-year surveillance for nosocomial and environmental Legionella pneumophila: Implications for infection control. Infect. Control. Hosp. Epidemiol. 2006, 27, 459-465. [CrossRef]

122. Sherertz, R.J.; Belani, A.; Kramer, B.S.; Elfenbein, G.J.; Weiner, R.S.; Sullivan, M.L.; Thomas, R.G.; Samsa, G.P. Impact of air filtration on nosocomial Aspergillus infections: Unique risk of bone marrow transplant recipients. Am. J. Med. 1987, 83, 709-718. [CrossRef]

123. Passamonte, P.M.; Dix, J.D. Nosocomial pulmonary mucormycosis with fatal massive hemoptysis. Am. J. Med Sci. 1985, 289, 65-67. [CrossRef]

124. Suzuki, T.; Tahara, H.; Narula, S.; Moore, K.W.; Robbins, P.D.; Lotze, M.T. Viral interleukin 10 (IL-10), the human herpes virus 4 cellular IL-10 homologue, induces local anergy to allogeneic and syngeneic tumors. J. Exp. Med. 1995, 182, 477-486. [CrossRef] [PubMed]

125. Hsueh, P.; Tseng, S.; Teng, L.; Ho, S. Pan-drug-resistant Pseudomonas aeruginosa causing nosocomial infection at a university hospital in Taiwan. Clin. Microbiol. Infect. 2005, 11, 670-673. [CrossRef] [PubMed]

126. Yew, W.W.; Leung, C.C. Management of multidrug-resistant tuberculosis: Update 2007. Respirology. 2007, 13, 21-46. [CrossRef] [PubMed]

127. Kallen, A.J.; Brunkard, J.; Moore, Z.; Budge, P.; Arnold, K.E.; Fosheim, G.; Finelli, L.; Beekmann, S.E.; Polgreen, P.; Gorwitz, R.; et al. Staphylococcus aureus community-acquired pneumonia during the 2006 to 2007 influenza season. Ann. Emerg. Med. 2009, 53, 358-365. [CrossRef]

128. Lackenby, A.; Hungnes, O.; Dudman, S.G.; Meijer, A.; Paget, W.J.; Hay, A.J.; Zambon, M.C. Emergence of resistance to oseltamivir among influenza $\mathrm{A}(\mathrm{H} 1 \mathrm{N1})$ viruses in Europe. Eurosurveillance 2008, 13, 3-4. [CrossRef]

129. Zhu, Z.; Lian, X.; Su, X.; Wu, W.; Marraro, G.A.; Zeng, Y. From SARS and MERS to COVID-19: A brief summary and comparison of severe acute respiratory infections caused by three highly pathogenic human coronaviruses. Respir. Res. 2020, 21, 224. [CrossRef] [PubMed]

130. Thomson, R.M.; Yew, W.-W. When and how to treat pulmonary non-tuberculous mycobacterial diseases. Respirology 2009, 14, 12-26. [CrossRef]

131. Singh, R.; Smitha, M.S.; Singh, S.P. The Role of Nanotechnology in combating multi-drug resistant bacteria. J. Nanosci. Nanotechnol. 2014, 14, 4745-4756. [CrossRef]

132. Natan, M.; Banin, E. From Nano to Micro: Using nanotechnology to combat microorganisms and their multidrug resistance. FEMS Microbiol. Rev. 2017, 41, 302-322. [CrossRef]

133. Hayat, S.; Muzammil, S.; Fakhar-E-Alam, M.; Aslam, B.; Siddique, M.H.; Nisar, M.A.; Saqalein, M.; Atif, M.; Sarwar, A.; Khurshid, A.; et al. Nanoantibiotics future nanotechnologies to combat antibiotic resistance. Front. Biosci. 2018, 10, 352-374. [CrossRef]

134. Slavin, Y.N.; Asnis, J.; Häfeli, U.O.; Bach, H. Metal nanoparticles: Understanding the mechanisms behind antibacterial activity. J. Nanobiotechnol. 2017, 15, 65. [CrossRef] [PubMed]

135. Borase, H.P.; Salunke, B.K.; Salunkhe, R.B.; Patil, C.D.; Hallsworth, J.E.; Kim, B.S.; Patil, S.V. Plant Extract: A Promising biomatrix for ecofriendly, controlled synthesis of silver nanoparticles. Appl. Biochem. Biotechnol. 2014, 173, 1-29. [CrossRef]

136. Mohammadinejad, R.; Shavandi, A.; Raie, D.S.; Sangeetha, J.; Soleimani, M.; Hajibehzad, S.S.; Thangadurai, D.; Hospet, R.; Popoola, J.O.; Arzani, A.; et al. Plant molecular farming: Production of metallic nanoparticles and therapeutic proteins using green factories. Green Chem. 2019, 21, 1845-1865. [CrossRef]

137. Iravani, S. Green synthesis of metal nanoparticles using plants. Green Chem. 2011, 13, 2638-2650. [CrossRef]

138. Mittal, A.K.; Chisti, Y.; Banerjee, U.C. Synthesis of metallic nanoparticles using plant extracts. Biotechnol. Adv. 2013, 31, 346-356. [CrossRef]

139. Lee, S.Y.; Krishnamurthy, S.; Cho, C.-W.; Yun, Y.-S. Biosynthesis of gold nanoparticles Using Ocimum sanctum extracts by solvents with different polarity. ACS Sustain. Chem. Eng. 2016, 4, 2651-2659. [CrossRef]

140. Lü, S.; Wu, Y.; Liu, H. Silver nanoparticles synthesized using Eucommia ulmoides bark and their antibacterial efficacy. Mater. Lett. 2017, 196, 217-220. [CrossRef]

141. Aiad, I.; Marzouk, M.; Shaker, S.A.; Ebrahim, N.E.; Abd-Elaal, A.; Tawfik, S.M. Antipyrine cationic surfactants capping silver nanoparticles as potent antimicrobial agents against pathogenic bacteria and fungi. J. Mol. Liq. 2017, 243, 572-583. [CrossRef]

142. Kuppusamy, P.; Ichwan, S.J.A.; Parine, N.R.; Yusoff, M.; Maniam, G.P.; Govindan, N. Intracellular biosynthesis of Au and Ag nanoparticles using ethanolic extract of Brassica oleracea L. and studies on their physicochemical and biological properties. $J$. Environ. Sci. 2015, 29, 151-157. [CrossRef] [PubMed]

143. Rosa, R.M.; Silva, J.C.; Sanches, I.S.; Henriques, C. Simultaneous photo-induced cross-linking and silver nanoparticle formation in a PVP electrospun wound dressing. Mater. Lett. 2017, 207, 145-148. [CrossRef]

144. Huy, T.Q.; Thanh, N.T.H.; Thuy, N.T.; Van Chung, P.; Hung, P.N.; Le, A.-T. Cytotoxicity and antiviral activity of electrochemicalsynthesized silver nanoparticles against poliovirus. J. Virol. Methods 2017, 241, 52-57. [CrossRef] [PubMed] 
145. Jannat, K.; Paul, A.K.; Bondhon, T.A.; Hasan, A.; Nawaz, M.; Jahan, R.; Mahboob, T.; Nissapatorn, V.; Wilairatana, P.; Pereira, M.D.L.; et al. Nanotechnology applications of flavonoids for viral diseases. Pharmaceutics 2021, 13, 1895. [CrossRef]

146. Sofy, A.R.; Hmed, A.A.; El Haliem, N.F.A.; Zein, M.A.-E.; Elshaarawy, R.F. Polyphosphonium-oligochitosans decorated with nanosilver as new prospective inhibitors for common human enteric viruses. Carbohydr. Polym. 2019, 226, 115261. [CrossRef] [PubMed]

147. Li, Y.; Lin, Z.; Xu, T.; Wang, C.; Zhao, M.; Xiao, M.; Wang, H.; Deng, N.; Zhu, B. Delivery of VP1 siRNA to inhibit the EV71 virus using functionalized silver nanoparticles through ROS-mediated signaling pathways. RSC Adv. 2017, 7, 1453-1463. [CrossRef]

148. Yang, X.X.; Li, C.M.; Huang, C.Z. Curcumin modified silver nanoparticles for highly efficient inhibition of respiratory syncytial virus infection. Nanoscale 2016, 8, 3040-3048. [CrossRef]

149. Li, Y.; Lin, Z.; Zhao, M.; Xu, T.; Wang, C.; Hua, L.; Wang, H.; Xia, H.; Zhu, B. Silver Nanoparticle based codelivery of ooeltamivir to inhibit the activity of the H1N1 influenza virus through ROS-mediated signaling pathways. ACS Appl. Mater. Interfaces 2016, 8 , 24385-24393. [CrossRef]

150. Du, T.; Liang, J.; Dong, N.; Lu, J.; Fu, Y.; Fang, L.; Xiao, S.; Han, H. Glutathione-capped Ag2S nanoclusters inhibit coronavirus proliferation through blockage of viral RNA synthesis and budding. ACS Appl. Mater. Interfaces 2018, 10, 4369-4378. [CrossRef]

151. Tavakoli, F.; Salavati-Niasari, M.; Ghanbari, D.; Saberyan, K.; Mashkani, S.M.H. Application of glucose as a green capping agent and reductant to fabricate CuI micro/nanostructures. Mater. Res. Bull. 2014, 49, 14-20. [CrossRef]

152. Gholami, T.; Salavati-Niasari, M.; Varshoy, S. Investigation of the electrochemical hydrogen storage and photocatalytic properties of $\mathrm{CoAl}_{2} \mathrm{O}_{4}$ pigment: Green synthesis and characterization. Int. J. Hydrogen Energy 2016, 41, 9418-9426. [CrossRef]

153. Verma, A.; Mehata, M. Controllable synthesis of silver nanoparticles using Neem leaves and their antimicrobial activity. J. Radiat. Res. Appl. Sci. 2016, 9, 109-115. [CrossRef]

154. Banerjee, P.; Satapathy, M.; Mukhopahayay, A.; Das, P. Leaf extract mediated green synthesis of silver nanoparticles from widely available Indian plants: Synthesis, characterization, antimicrobial property and toxicity analysis. Bioresour. Bioprocess. 2014, 1, 3. [CrossRef]

155. Saware, K.; Venkataraman, A. Biosynthesis and characterization of stable silver nanoparticles Using Ficus religiosa leaf extract: A mechanism perspective. J. Clust. Sci. 2014, 25, 1157-1171. [CrossRef]

156. Jha, A.K.; Prasad, K.; Prasad, K.; Kulkarni, A. Plant system: Nature's nanofactory. Colloids Surf. B Biointerfaces 2009, 73, 219-223. [CrossRef] [PubMed]

157. Bartczak, D.; Muskens, O.L.; Sanchez-Elsner, T.; Kanaras, A.G.; Millar, T.M. Manipulation of in vitro angiogenesis using peptidecoated gold nanoparticles. ACS Nano 2013, 7, 5628-5636. [CrossRef]

158. El-Gaffary, M.; Bashandy, M.M.; Ahmed, A.R.; El-Borady, O.M. Self-assembled gold nanoparticles for in-vitro inhibition of bovine viral diarrhea virus as surrogate model for HCV. Mater. Res. Express 2019, 6, 075075. [CrossRef]

159. Sametband, M.; Shukla, S.; Meningher, T.; Hirsh, S.; Mendelson, E.; Sarid, R.; Gedanken, A.; Mandelboim, M. Effective multi-strain inhibition of influenza virus by anionic gold nanoparticles. Med. Chem. Comm. 2011, 2, 421-423. [CrossRef]

160. Botteon, C.E.A.; Silva, L.B.; Ccana-Ccapatinta, G.V.; Silva, T.S.; Ambrosio, S.R.; Veneziani, R.C.S.; Bastos, J.K.; Marcato, P.D. Biosynthesis and characterization of gold nanoparticles using Brazilian red propolis and evaluation of its antimicrobial and anticancer activities. Sci. Rep. 2021, 11, 1-16. [CrossRef]

161. Haimov, E.; Weitman, H.; Polani, S.; Schori, H.; Zitoun, D.; Shefi, O. Meso-tetrahydroxyphenylchlorin-conjugated gold nanoparticles as a tool To improve photodynamic therapy. ACS Appl. Mater. Interfaces 2018, 10, 2319-2327. [CrossRef]

162. Lee, E.C.; Davis-Poynter, N.; Nguyen, C.T.H.; Peters, A.A.; Monteith, G.R.; Strounina, E.; Popat, A.; Ross, B.P. GAG mimetic functionalised solid and mesoporous silica nanoparticles as viral entry inhibitors of herpes simplex type 1 and type 2 viruses. Nanoscale 2016, 8, 16192-16196. [CrossRef] [PubMed]

163. Fahmi, M.Z.; Sukmayani, W.; Khairunisa, S.Q.; Witaningrum, A.M.; Indriati, D.W.; Matondang, M.Q.Y.; Chang, J.-Y.; Kotaki, T.; Kameoka, M. Design of boronic acid-attributed carbon dots on inhibits HIV-1 entry. RSC Adv. 2016, 6, 92996-93002. [CrossRef]

164. Tong, T.; Hu, H.; Zhou, J.; Deng, S.; Zhang, X.; Tang, W.; Fang, L.; Xiao, S.; Liang, J. Glycyrrhizic-acid-based carbon dots with high antiviral activity by multisite inhibition mechanisms. Small 2020, 16, e1906206. [CrossRef] [PubMed]

165. Du, X.; Xiao, R.; Fu, H.; Yuan, Z.; Zhang, W.; Yin, L.; He, C.; Li, C.; Zhou, J.; Liu, G.; et al. Hypericin-loaded graphene oxide protects ducks against a novel duck reovirus. Mater. Sci. Eng. C 2019, 105, 110052. [CrossRef]

166. Donskyi, I.S.; Azab, W.; Cuellar-Camacho, J.L.; Guday, G.; Lippitz, A.; Unger, W.E.S.; Osterrieder, K.; Adeli, M.; Haag, R Functionalized nanographene sheets with high antiviral activity through synergistic electrostatic and hydrophobic interactions. Nanoscale 2019, 11, 15804-15809. [CrossRef]

167. Ocsoy, I.; Temiz, M.; Celik, C.; Altinsoy, B.; Yilmaz, V.; Duman, F. A green approach for formation of silver nanoparticles on magnetic graphene oxide and highly effective antimicrobial activity and reusability. J. Mol. Liq. 2017, 227, 147-152. [CrossRef]

168. Lin, Z.; Li, Y.; Gong, G.; Xia, Y.; Wang, C.; Chen, Y.; Hua, L.; Zhong, J.; Tang, Y.; Liu, X.; et al. Restriction of H1N1 influenza virus infection by selenium nanoparticles loaded with ribavirin via resisting caspase-3 apoptotic pathway. Int. J. Nanomed. 2018, 13, 5787-5797. [CrossRef]

169. Agelidis, A.; Koujah, L.; Suryawanshi, R.; Yadavalli, T.; Mishra, Y.K.; Adelung, R.; Shukla, D. An intra-vaginal zinc oxide tetrapod nanoparticles (ZOTEN) and genital herpesvirus cocktail can provide a novel platform for live virus vaccine. Front. Immunol. 2019, 10, 500. [CrossRef] 
170. Ashraf, A.S.; Farideh, N.; Hamidreza, M.; Parichehre, Y.; Mahboobeh, N.M. Assessment of antioxidant and antibacterial activities of zinc oxide nanoparticles, graphene and graphene decorated by zinc oxide nanoparticles. Int. J. Nano Dimens. 2019, 10, 350-358.

171. Veisi, H.; Kavian, M.; Hekmati, M.; Hemmati, S. Biosynthesis of the silver nanoparticles on the graphene oxide's surface using Pistacia atlantica leaves extract and its antibacterial activity against some human pathogens. Polyhedron 2019, 161, 338-345. [CrossRef]

172. Zilker, C.; Kozlova, D.; Sokolova, V.; Yan, H.; Epple, M.; Überla, K.; Temchura, V. Nanoparticle-based B-cell targeting vaccines: Tailoring of humoral immune responses by functionalization with different TLR-ligands. Nanomed. Nanotechnol. Biol. Med. 2017, 13, 173-182. [CrossRef] [PubMed]

173. Rezaei, M.; Hosseini, S.N.; Khavari-Nejad, R.A.; Najafi, F.; Mahdavi, M. HBs antigen and mannose loading on the surface of iron oxide nanoparticles in order to immuno-targeting: Fabrication, characterization, cellular and humoral immunoassay. Artif. Cells Nanomed. Biotechnol. 2019, 47, 1543-1558. [CrossRef] [PubMed]

174. Pimentel, T.A.P.F.; Yan, Z.; Jeffers, S.A.; Holmes, K.V.; Hodges, R.S.; Burkhard, P. Peptide nanoparticles as novel immunogens: Design and analysis of a Ppototypic severe acute respiratory syndrome vaccine. Chem. Biol. Drug Des. 2009, 73, 53-61. [CrossRef] [PubMed]

175. Geng, Q.; Tai, W.; Baxter, V.K.; Shi, J.; Wan, Y.; Zhang, X.; Montgomery, S.A.; Taft-Benz, S.A.; Anderson, E.J.; Knight, A.C.; et al. Novel virus-like nanoparticle vaccine effectively protects animal model from SARS-CoV-2 infection. PLoS Pathog. 2021, 17, e1009897. [CrossRef]

176. Coleman, C.; Liu, Y.V.; Mu, H.; Taylor, J.K.; Massare, M.; Flyer, D.C.; Glenn, G.M.; Smith, G.E.; Frieman, M.B. Purified coronavirus spike protein nanoparticles induce coronavirus neutralizing antibodies in mice. Vaccine 2014, 32, 3169-3174. [CrossRef]

177. Barlow, P.G.; Clouter-Baker, A.; Donaldson, K.; MacCallum, J.; Stone, V. Carbon black nanoparticles induce type II epithelial cells to release chemotaxins for alveolar macrophages. Part. Fibre Toxicol. 2005, 2, 1-14. [CrossRef]

178. Gurr, J.-R.; Wang, A.S.; Chen, C.-H.; Jan, K.-Y. Ultrafine titanium dioxide particles in the absence of photoactivation can induce oxidative damage to human bronchial epithelial cells. Toxicology 2005, 213, 66-73. [CrossRef]

179. Li, J.; Li, Q.; Xu, J.; Li, J.; Cai, X.; Liu, R.; Li, Y.; Ma, J.; Li, W. Comparative study on the acute pulmonary toxicity induced by 3 and $20 \mathrm{~nm} \mathrm{TiO} 2$ primary particles in mice. Environ. Toxicol. Pharmacol. 2007, 24, 239-244. [CrossRef]

180. Cummins, G.; Lay, H.; Cox, B.; Seetohul, V.; Qiu, Y.; Stewart, F.; Faerber, J.; Mitrakos, V.; Al Rawhani, M.; Beeley, J.; et al. Sonopill: A platform for gastrointestinal disease diagnosis and therapeutics. In Proceedings of the 6th Joint Workshop on New Technologies for Computer/Robot Assisted Surgery, Pisa, Italy, 12-14 September 2016.

181. Scaldaferri, F.; Pizzoferratom, M.; Gerardim, V.; Lopetuso, L.; Gasbarrini, A. The gut barrier. J. Clin. Gastroenterol. 2012, 46, S12-S17. [CrossRef]

182. Lopetuso, L.R.; Petito, V.; Graziani, C.; Schiavoni, E.; Sterbini, F.P.; Poscia, A.; Gaetani, E.; Franceschi, F.; Cammarota, G.; Sanguinetti, M.; et al. Gut microbiota in health, diverticular disease, irritable bowel syndrome, and inflammatory bowel diseases: Time for microbial marker of gastrointestinal disorders. Dig. Dis. 2017, 36, 56-65. [CrossRef]

183. Daniels, L.; Philipszoon, L.E.; Boermeester, M.A. A Hypothesis. Dis. Colon Rectum 2014, 57, 539-543. [CrossRef] [PubMed]

184. Paul, A.K.; Paul, A.; Jahan, R.; Jannat, K.; Bondhon, T.A.; Hasan, A.; Nissapatorn, V.; Pereira, M.L.; Wilairatana, P.; Rahmatullah, M. Probiotics and amelioration of rheumatoid arthritis: Significant roles of Lactobacillus casei and Lactobacillus acidophilus. Microorganisms 2021, 9, 1070. [CrossRef] [PubMed]

185. Chang, C.; Lin, H. Dysbiosis in gastrointestinal disorders. Best Pract. Res. Clin. Gastroenterol. 2016, 30, 3-15. [CrossRef] [PubMed]

186. Mayer, E.A.; Savidge, T.; Shulman, R.J. Brain-gut microbiome interactions and functional bowel disorders. Gastroenterology 2014, 146, 1500-1512. [CrossRef] [PubMed]

187. Heya, M.; David Torres-Hernández, Á.; Heya, M.S.; Torres Hernández, A.D.; Cordero Díaz, A.; García Coronado, P.L. Biomedical apllication of nanoformulated plant Diagnóstico de las dermatofitosis View project Biomedical apllication of nanoformulated plant View project Biomedical apllication of nanoformulated plant. Artic. Int. J. Pharm. Sci. Res. 2022, 13, 1000. [CrossRef]

188. Ryan, E.T.; Hill, D.R.; Solomon, T.; Aronson, N.; Endy, T.P. Hunter's Tropical Medicine and Emerging Infectious Diseases E-Book, 10th ed.; Elsevier: Amsterdam, The Netherlands, 2020; ISBN 9780323555128.

189. Madureira, A.R.; Pereira, A.; Pintado, M. Current state on the development of nanoparticles for use against bacterial gastrointestinal pathogens. Focus on chitosan nanoparticles loaded with phenolic compounds. Carbohydr. Polym. 2015, 130, 429-439. [CrossRef] 